\title{
The Australian bushfires of February 2009: MIPAS observations and GEM-AQ model results
}

\author{
N. Glatthor ${ }^{1}$, M. Höpfner ${ }^{1}$, K. Semeniuk ${ }^{2}$, A. Lupu ${ }^{2}$, P. I. Palmer ${ }^{3}$, J. C. McConnell ${ }^{2}$, J. W. Kaminski ${ }^{2}$, \\ T. von Clarmann ${ }^{1}$, G. P. Stiller ${ }^{1}$, B. Funke ${ }^{4}$, S. Kellmann ${ }^{1}$, A. Linden ${ }^{1}$, and A. Wiegele ${ }^{1}$ \\ ${ }^{1}$ Karlsruher Institut für Technologie, Institut für Meteorologie und Klimaforschung, Karlsruhe, Germany \\ ${ }^{2}$ Centre for Research in Earth and Space Science, York University, Toronto, Canada \\ ${ }^{3}$ School of GeoSciences, University of Edinburgh, Edinburgh, UK \\ ${ }^{4}$ Instituto de Astrofísica de Andalucía (CSIC), Granada, Spain \\ Correspondence to: N. Glatthor (norbert.glatthor@kit.edu)
}

Received: 5 April 2012 - Published in Atmos. Chem. Phys. Discuss.: 12 June 2012

Revised: 7 December 2012 - Accepted: 21 January 2013 - Published: 8 February 2013

\begin{abstract}
Starting on 7 February 2009, southeast Australia was devastated by large bushfires, which burned an area of about $3000 \mathrm{~km}^{2}$ on this day alone. This event was extraordinary, because a large number of combustion products were transported into the uppermost troposphere and lower stratosphere within a few days. Various biomass burning products released by the fire were observed by the Michelson Interferometer for Passive Atmospheric Sounding (MIPAS) on the Envisat satellite. We tracked the plume using MIPAS $\mathrm{C}_{2} \mathrm{H}_{2}$, $\mathrm{HCN}$ and $\mathrm{HCOOH}$ single-scan measurements on a day-today basis. The measurements were compared with a highresolution model run of the Global Environmental Multiscale Air Quality (GEM-AQ) model. Generally there is good agreement between the spatial distribution of measured and modelled pollutants. Both MIPAS and GEM-AQ show a fast southeastward transport of the pollutants to New Zealand within one day. During the following 3-4 days, the plume remained northeastward of New Zealand and was located at altitudes of 15 to $18 \mathrm{~km}$. Thereafter its lower part was transported eastward, followed by westward transport of its upper part. On 17 February the eastern part had reached southern South America and on 20 February the central South Atlantic. On the latter day a second relic of the plume was observed moving eastward above the South Pacific. Between 20 February and the first week of March, the upper part of the plume was transported westward over Australia and the Indian Ocean towards southern Africa. First evidence for entry of the pollutants into the stratosphere was found in MIPAS data of 11 February, followed by larger amounts on 17 Febru-
\end{abstract}

ary and the days thereafter. From MIPAS data, $\mathrm{C}_{2} \mathrm{H}_{2} / \mathrm{HCN}$ and $\mathrm{HCOOH} / \mathrm{HCN}$ enhancement ratios of 0.76 and 2.16 were calculated for the first days after the outbreak of the fires, which are considerably higher than the emission ratios assumed for the model run and at the upper end of values found in literature. From the temporal decrease of the enhancement ratios, mean lifetimes of 16-20 days and of 8-9 days were calculated for measured $\mathrm{C}_{2} \mathrm{H}_{2}$ and $\mathrm{HCOOH}$. The respective lifetimes calculated from the model data are 18 and 12 days.

\section{Introduction}

Biomass burning is one of the major sources of anthropogenic tropospheric pollution (Singh et al., 1996, 2000; $\mathrm{Li}$ et al., 2003). While the main combustion products are $\mathrm{CO}_{2}$, water vapour and smoke, a large suite of short-lived and longer-lived organic and a few inorganic species are also generated. Important biomass burning products are carbon monoxide $(\mathrm{CO})$, ethane $\left(\mathrm{C}_{2} \mathrm{H}_{6}\right)$, acetylene $\left(\mathrm{C}_{2} \mathrm{H}_{2}\right)$, methanol $\left(\mathrm{CH}_{3} \mathrm{OH}\right)$, hydrogen cyanide $(\mathrm{HCN})$, acetonitrile $\left(\mathrm{CH}_{3} \mathrm{CN}\right)$, peroxyacetyl nitrate $\left(\mathrm{PAN}, \mathrm{CH}_{3} \mathrm{C}(\mathrm{O}) \mathrm{OONO}_{2}\right)$ and formic acid $(\mathrm{HCOOH}) . \mathrm{HCN}$ and $\mathrm{CH}_{3} \mathrm{CN}$ are nearly exclusively produced by biomass burning ( $\mathrm{Li}$ et al., 2003; Singh et al., 2003; Yokelson et al., 2007; Lupu et al., 2009). By fireinduced convection or favourable meteorological conditions, significant amounts of these pollutants can be transported into the free troposphere (Donnell et al., 2001; Kahn et al., 2007). Since the tropospheric lifetime of most of these trace 
gases is several weeks, they can form persistent upper tropospheric plumes. A prominent example is the southern hemispheric biomass burning plume caused by continuous combustion throughout the dry season in South America, central and southern Africa and Australia, which regularly peaks between September and November. The spatial extension and composition of this plume has been investigated using various ground-based, airborne and spaceborne observations (Singh et al., 1996, 2000; Rinsland et al., 2001, 2005; von Clarmann et al., 2007; Glatthor et al., 2009). Another region of long-lasting upper tropospheric pollution is the Asian monsoon anticyclone, which typically forms above southern Asia in June, July and August (Park et al., 2008). Due to the relatively low signal-to-noise ratio and cloud contamination, temporal and spatial averaging has been performed for the larger part of spaceborne observations of biomass burning products published so far.

At the beginning of February 2009, the state of Victoria in southeastern Australia was devastated by the most disastrous bushfires in terms of the number of fatalities (173 people died) that had ever taken place in Australia (Tolhurst, 2009). The total burned area amounted to about $3000 \mathrm{~km}^{2}$, most of it being burned on 7 February 2009, the so-called "Black Saturday" (Tolhurst, 2009). The Royal Commission report even states an area of $4300 \mathrm{~km}^{2}$ burned in early 2009 (Teague et al., 2010). The largest of these fires was the Kilmore East fire $85 \mathrm{~km}$ north of Melbourne. This fire, caused by a failure of electrical power lines, started around midday local time on 7 February and was declared contained on 16 February (Teague et al., 2010). An area of about $1250 \mathrm{~km}^{2}$ was burned, the major part of it $\left(1150 \mathrm{~km}^{2}\right)$ on 7 February (Tolhurst, 2009). The fire-driven convection was sufficient to loft the pollutants high into the troposphere, and further enhanced by a low-pressure trough, which passed over the area ahead of a cold front and led to an unstable atmosphere. At around 19:30 LT the fire-induced pyrocumulus cloud was estimated to be $8.5 \mathrm{~km}$ high (Tolhurst, 2009), but it likely penetrated to higher altitudes in the following night. Within three days after the outbreak of the fire, the smoke plume had drifted to the north of New Zealand and was further lifted to altitudes of $15-20 \mathrm{~km}$, which made this fire an extraordinary event. The mechanism for this subsequent lifting is still under investigation. De Laat et al. (2012) propose heating of the smoke or aerosol particles by shortwave solar radiation.

Detection of combustion products of this event in the upper troposphere and lower stratosphere by the Microwave Limb Sounder (MLS) on Aura has been reported by Pumphrey et al. (2011). MLS observed a CO plume, which was located north and eastward of New Zealand during the first week after the outbreak of the fire. In the second week the $\mathrm{CO}$ plume extended up to $46 \mathrm{hPa}(\sim 21 \mathrm{~km})$ and was distorted in southeastern direction, followed by a westward drift of the stratospheric portion of the plume over Australia and the Indian Ocean during the next two weeks. Pumphrey et al. (2011) pointed out the unusual injection height of the pol- lutants reaching up into the stratosphere. In a statistical investigation they documented the uniqueness of this event in the MLS dataset. MLS observations are supported by measurements of the Optical Spectrograph and Infrared Imager System (OSIRIS) on the Odin satellite, which detected smoke particles from the Australian fire in the lower stratosphere around 11 February 2009 (Siddaway and Petelina, 2011). Driven by the westward phase of the quasi-biennial oscillation (QBO), these particles travelled westward in the southern tropics and circled the globe in about 6 weeks. In another paper Clarisse et al. (2011) report on signatures of various biomass burning products detected in nadir spectra of the Infrared Atmospheric Sounding Interferometer (IASI) obtained in the plume of the Australian bushfires.

The Australian bushfire plume was a rather isolated event not much disturbed by other fires, since the southern hemispheric biomass burning plume caused by widespread combustion in South America and southern Africa had widely disappeared by this time of the year (Glatthor et al., 2009). Further, the plume reached extraordinarily high altitudes, where clouds are less frequent allowing a better sampling of the atmosphere by infrared satellite limb measurements. In this paper we track the spatial expansion of the plume using single-scan measurements of $\mathrm{C}_{2} \mathrm{H}_{2}, \mathrm{HCN}$ and $\mathrm{HCOOH}$ by the Michelson Interferometer for Passive Atmospheric Sounding (MIPAS) on Envisat in comparison with highresolution simulations of the GEM-AQ (Global Environmental Multiscale Air Quality) model. HCN is a nearly unambiguous tracer of biomass burning ( $\mathrm{Li}$ et al., 2003; Singh et al., 2003; Yokelson et al., 2007). $\mathrm{C}_{2} \mathrm{H}_{2}$ is another, although not unambiguous biomass burning tracer (Singh et al., 1996), and $\mathrm{HCOOH}$ has additional (e.g. biogenic) tropospheric sources (Keene and Galloway, 1988; Grutter et al., 2010; Stavrakou et al., 2012). The upper tropospheric lifetime of $\mathrm{HCN}$ is 5-6 months ( $\mathrm{Li}$ et al., 2003; Lupu et al., 2009). Estimates for the lifetime of $\mathrm{C}_{2} \mathrm{H}_{2}$ vary between 2 weeks (Xiao et al., 2007) and 50 days (Rudolph et al., 1984), and for $\mathrm{HCOOH}$ between several days and a few weeks (Grutter et al., 2010). In Sects. 2 and 3 we will describe the technical aspects of the MIPAS measurements, the retrieval setup and the GEM-AQ model, respectively. In Sect. 4 we will compare measured and model data to analyse the transport and chemical processing of the pollutants. In Sect. 5 we will summarise the detected transport pattern, plume aging and evaluate the comparison between MIPAS and GEM-AQ results.

\section{MIPAS measurements}

\subsection{Instrument description}

On 1 March 2002, the European environmental satellite (Envisat) was launched into a Sun-synchronous polar orbit at about $800 \mathrm{~km}$ altitude. The satellite performs 14.3 orbits 
per day and passes the Equator at $\sim 10: 00 \mathrm{LT}$ and $\sim 22: 00$ LT. Among various other experiments, Envisat hosts the Michelson Interferometer for Passive Atmospheric Sounding (MIPAS). MIPAS is a limb-viewing Fourier transform infrared (FTIR) emission spectrometer covering the midinfrared spectral region between 685 and $2410 \mathrm{~cm}^{-1}(4.1-$ $14.6 \mu \mathrm{m}$ ), which enables simultaneous observation of numerous trace gases (European Space Agency (ESA), 2000, Fischer et al., 2008).

Since March 2004 MIPAS has been operated in the socalled reduced resolution (RR) measurement mode with a spectral resolution of $0.121 \mathrm{~cm}^{-1}$ (full-width at half maximum after Norton-Beer "strong" apodization) and a latitudinal sampling distance of $\sim 3.6^{\circ}(400 \mathrm{~km})$. The acrosstrack coverage of MIPAS is $30 \mathrm{~km}$. We present data of the RR "nominal" measurement mode, consisting of rearward limb-scans covering the altitude region between 7 and $72 \mathrm{~km}$ within 27 altitude steps. The step-width is $1.5 \mathrm{~km}$ up to $22 \mathrm{~km}, 2 \mathrm{~km}$ up to $32 \mathrm{~km}, 3 \mathrm{~km}$ up to $44 \mathrm{~km}$ and $4-4.5 \mathrm{~km}$ for the upper part of the scan. MIPAS is able to measure during day and night, and produces up to 1400 scans per day in RR nominal mode. The level-1B radiance spectra used for retrieval are data version 4.67 (reprocessed data) provided by the European Space Agency (ESA) (Nett et al., 2002).

\subsection{Retrieval method and error estimation}

We present $\mathrm{C}_{2} \mathrm{H}_{2}, \mathrm{HCN}$ and $\mathrm{HCOOH}$ distributions and additionally some example $\mathrm{C}_{2} \mathrm{H}_{6}$, PAN and $\mathrm{CO}$ profiles measured by MIPAS-Envisat. The respective data versions are V4O_C2H2_200, V4O_HCN_201, V4O_HCOOH_200, V4O_C2H6_200, V4O_PAN_200 and V4O_CO_200 of the MIPAS RR mode. Processing of MIPAS data at IMK has been described in various papers (von Clarmann et al., 2003; Höpfner et al., 2004). Retrieval of $\mathrm{C}_{2} \mathrm{H}_{2}, \mathrm{HCN}, \mathrm{HCOOH}$, $\mathrm{C}_{2} \mathrm{H}_{6}$ and $\mathrm{CO}$ has been discussed by Wiegele et al. (2012), Glatthor et al. (2009), Grutter et al. (2010), von Clarmann et al. (2007) and Funke et al. (2009). Therefore we will give only a short description of the retrieval setups.

The datasets were produced with the retrieval processor of the Institut für Meteorologie und Klimaforschung and the Instituto de Astrofísica de Andalucía (IMK/IAA). Radiative transfer calculations were performed with the Karlsruhe Optimized and Precise Radiative Algorithm (KOPRA) (Stiller, 2000) and the retrievals with the Retrieval Control Program (RCP) of IMK/IAA. The retrievals consist of inversion of MIPAS level-1B spectra to vertical profiles of atmospheric state parameters by constrained non-linear least squares fitting in a global-fit approach (von Clarmann et al., 2003). Tikhonov's first derivative operator is used as a constraint (Steck, 2002, and references therein). A constraint is necessary to attenuate instabilities, since the retrieval grid has a finer altitude spacing than the height distance between the tangent altitudes. To avoid any influence of the a priori information on the shape of the retrieved profiles, height-constant a priori profiles were chosen. For retrieval of $\mathrm{C}_{2} \mathrm{H}_{2}$ and $\mathrm{HCN}, \mathrm{O}_{3}$ was joint-fitted, and for retrieval of $\mathrm{HCOOH} \mathrm{O}_{3}$, CFC-11 and CFC-22. Additional retrieval parameters were microwindow-dependent continuum radiation profiles and microwindow-dependent but height-independent zero-level calibration corrections. To account for other contaminating gases, their profiles as retrieved earlier in the processing sequence were used. When no prefitted profiles were available, we used the data of the MIPAS climatology (Remedios et al., 2007).

Figure 1 shows MIPAS single-scan profiles of $\mathrm{C}_{2} \mathrm{H}_{2}$, $\mathrm{HCN}, \mathrm{C}_{2} \mathrm{H}_{6}$, PAN, $\mathrm{HCOOH}$ and $\mathrm{CO}$ obtained at three different geolocations. The first set of profiles was measured on 7 February over the South Pacific in an unpolluted atmosphere (top left), and the two other sets on 17 February 2009, inside the Australian plume (middle and bottom left). All profiles measured in the unpolluted atmosphere (top left) exhibit typical background values. $\mathrm{CO}$ amounts to $40 \mathrm{ppbv}$ at $13 \mathrm{~km}$, and $\mathrm{HCN}$ has a nearly height-constant profile of 200-230 pptv, which is due to its atmospheric lifetime of $\sim 5.3$ months in the troposphere (Li et al., 2003) and $\sim 2.5 \mathrm{yr}$ in the stratosphere (Cicerone and Zellner, 1983). The background $\mathrm{C}_{2} \mathrm{H}_{6}$ profile is strongly oscillating. Inside the plume each of the six pollutants in remarkable agreement has a pronounced maximum in the height region between 16 and $18 \mathrm{~km}$. Maximum volume mixing ratios range from $100 \mathrm{pptv}$ $\left(\mathrm{C}_{2} \mathrm{H}_{2}, \mathrm{C}_{2} \mathrm{H}_{6}\right)$ to $500 \mathrm{pptv}$ for $\mathrm{HCN}$ and to $100 \mathrm{ppbv}$ for $\mathrm{CO}$, and are well above background values. The maxima are all above the tropopause (dashed curves) derived from MIPAS temperature profiles.

Except for $\mathrm{C}_{2} \mathrm{H}_{6}$, the maxima of all pollutants distinctively exceed the estimated retrieval error (Fig. 1, right column). Compared to the other species, the estimated retrieval error of $\mathrm{C}_{2} \mathrm{H}_{6}$ is unusually high. More detailed error analyses of the different species including systematic errors are presented in Wiegele et al. (2012). The vertical resolution between 15 and $21 \mathrm{~km}$ is as follows: about 3.5 to $6.5 \mathrm{~km}$ for $\mathrm{C}_{2} \mathrm{H}_{2}$ and PAN, 4 to $6.5 \mathrm{~km}$ for $\mathrm{HCOOH}, 4.5$ to $6 \mathrm{~km}$ for $\mathrm{HCN}, 5$ to $8 \mathrm{~km}$ for $\mathrm{C}_{2} \mathrm{H}_{6}$ and 6 to $6.5 \mathrm{~km}$ for $\mathrm{CO}$.

In Table 1 we list mean values, standard deviations $(\sigma)$ and upper thresholds for strong outliers of background distributions of southern hemispheric $\mathrm{C}_{2} \mathrm{H}_{2}, \mathrm{HCN}$ and $\mathrm{HCOOH}$ averaged over the time period 1 January to 7 February 2009. $\mathrm{C}_{2} \mathrm{H}_{2}, \mathrm{HCN}$ and $\mathrm{HCOOH}$ amounts exceeding the given thresholds can be attributed to pollution events with high confidence.

\subsection{Uniqueness of the Australian plume}

To point out the uniqueness of the Australian bushfire with respect to plume height, Fig. 2 shows two time series of MIPAS $\mathrm{C}_{2} \mathrm{H}_{2}$ data from the latitude band between the Equator and $60^{\circ} \mathrm{S}$, measured at 18 and $21 \mathrm{~km}$ altitude. Both datasets exhibit background values of up to $30 \mathrm{pptv}$ before the outbreak of the fire (day 37, 7 February) and from about day 75 

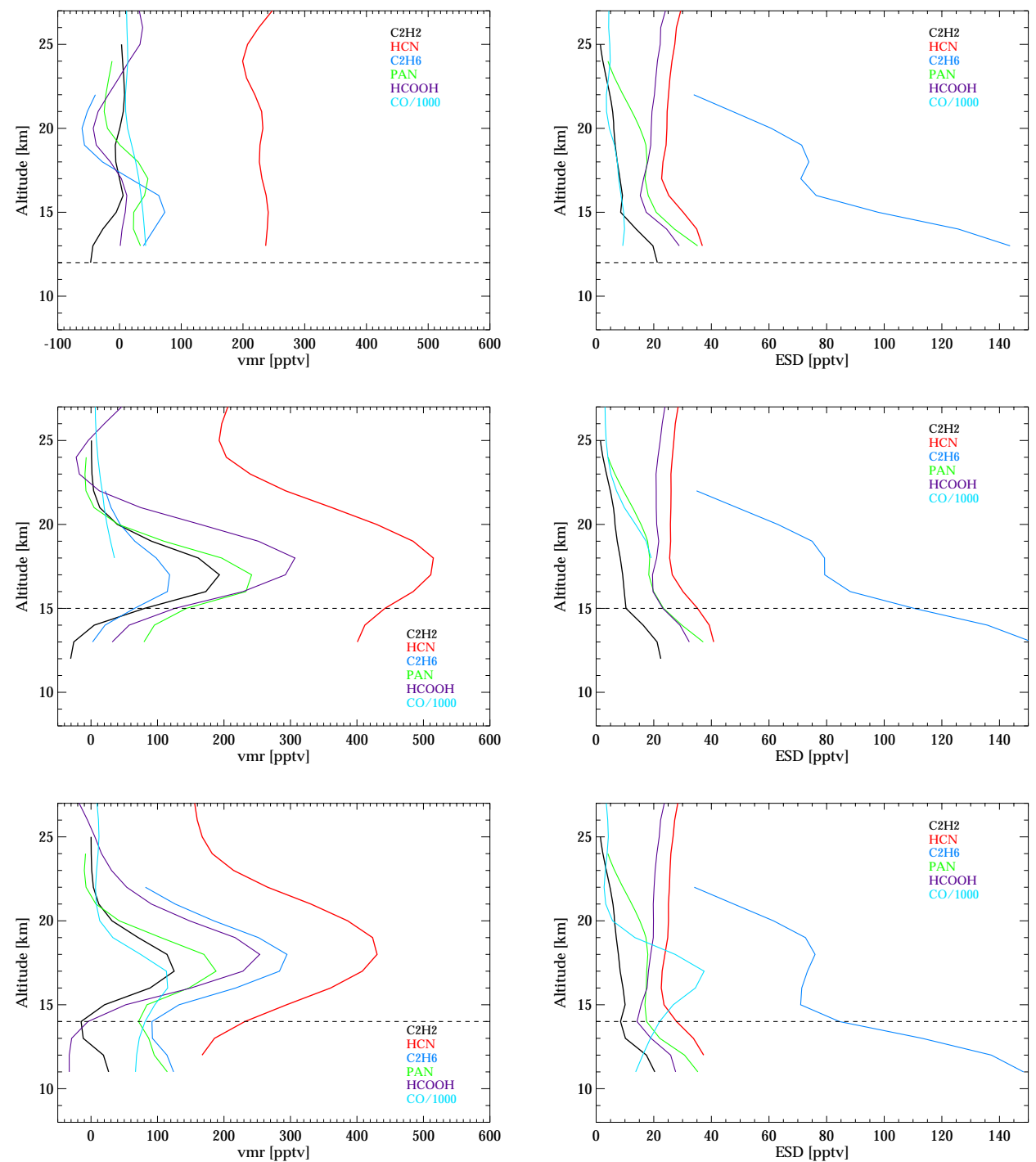

Fig. 1. Upper row: (left) VMR profiles of $\mathrm{C}_{2} \mathrm{H}_{2}, \mathrm{HCN}, \mathrm{C}_{2} \mathrm{H}_{6}, \mathrm{PAN}, \mathrm{HCOOH}$ and $\mathrm{CO}$, measured by MIPAS on 7 February 2009 , in an unpolluted atmosphere over the central South Pacific. CO amounts are in ppbv and scaled down by a factor of 1000. (right) Corresponding estimated retrieval error. Dashed line indicates the altitude of the thermal tropopause. Middle and lower row: same as upper row, but for MIPAS measurements on 17 February 2009 , inside the Australian bushfire plume. The measurements were made at $38.9^{\circ} \mathrm{S}, 151.7^{\circ} \mathrm{W}$ (top); $33.7^{\circ} \mathrm{S}, 146.8^{\circ} \mathrm{W}$ (middle); and at $38.9^{\circ} \mathrm{S}, 148.1^{\circ} \mathrm{W}$ (bottom).

(17 March) until the end of the displayed time period (31 October). After the outbreak of the fire, there was an abrupt increase of maximum $\mathrm{C}_{2} \mathrm{H}_{2}$ amounts of up to $280 \mathrm{pptv}$ at $18 \mathrm{~km}$ and a somewhat slower increase of up to $130 \mathrm{pptv}$ at $21 \mathrm{~km}$ altitude, lasting for some weeks. The $\mathrm{C}_{2} \mathrm{H}_{2}$ data peak at days 43-44 (13-14 February) at $18 \mathrm{~km}$ altitude and around day 59 (1 March) at $21 \mathrm{~km}$ altitude. At both altitudes enhanced $\mathrm{C}_{2} \mathrm{H}_{2}$ values persist until mid-March. The time series also includes the peak of the main southern hemispheric biomass burning season in October, but pollutants released during this event never reached such high altitudes.

\section{GEM-AQ model setup}

In order to simulate the release of pollutants by the "Black Saturday" fires, we used the Global Environmental Multiscale Air Quality (GEM-AQ) model (Kaminski et al., 2008), a tropospheric chemistry general circulation model based on the global variable resolution multiscale GEM model developed by the Meteorological Service of Canada for operational weather prediction (Côté et al., 1998a, b). The version of GEM-AQ employed in this study uses GEM version 3.3.2 with physics package version 5.0.4 and was run in global variable $(\mathrm{GV})$ mode, i.e. with a uniform interior grid. All species are advected using the semi-Lagrangian scheme 

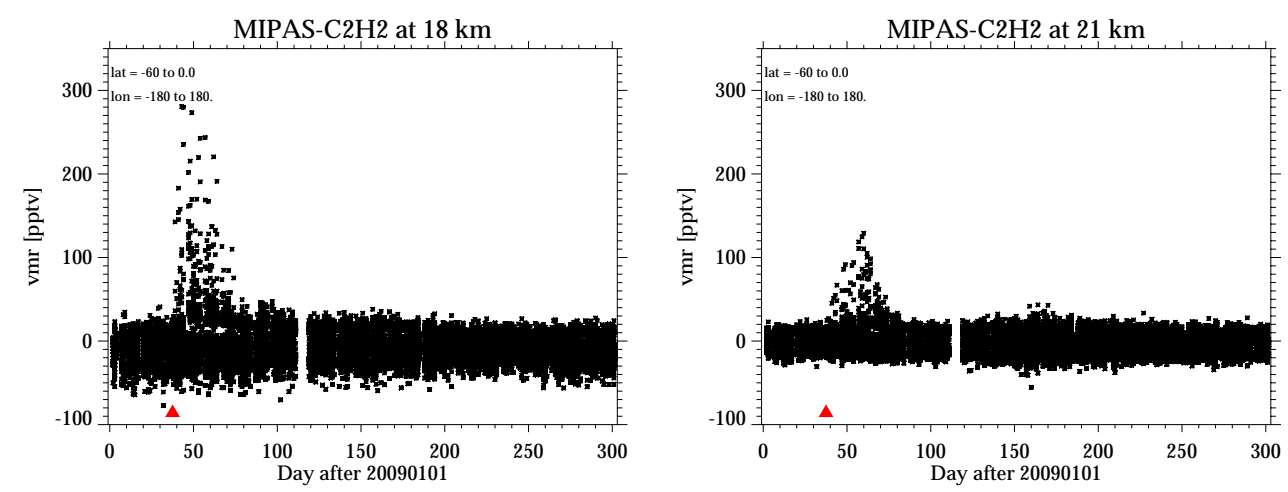

Fig. 2. MIPAS $\mathrm{C}_{2} \mathrm{H}_{2}$ data in the latitude band $60^{\circ} \mathrm{S}$ to $0^{\circ} \mathrm{N}$ for the time period 1 January to 31 October 2009 , measured at $18 \mathrm{~km}$ (left) and $21 \mathrm{~km}$ altitude (right). The red triangle indicates the date of the outbreak of the Australian bushfires (7 February).

Table 1. Mean values, scatter and upper thresholds for outliers of southern hemispheric $\mathrm{C}_{2} \mathrm{H}_{2}, \mathrm{HCN}$, and $\mathrm{HCOOH}$ measured by MIPAS during background conditions, averaged over the period 1 January to 7 February 2009.

\begin{tabular}{lrrrr}
\hline Gas & $\begin{array}{r}\text { Height } \\
{[\mathrm{km}]}\end{array}$ & $\begin{array}{r}\text { Mean VMR } \\
{[\mathrm{pptv}]}\end{array}$ & $\begin{array}{r}\text { Std dev } \\
{[\mathrm{pptv}]}\end{array}$ & $\begin{array}{r}\text { Mean + } \\
3 \sigma\end{array}$ \\
\hline $\mathrm{C}_{2} \mathrm{H}_{2}$ & 15 & 3.0 & 17.8 & 56.4 \\
$\mathrm{C}_{2} \mathrm{H}_{2}$ & 18 & -8.1 & 9.4 & 20.1 \\
$\mathrm{C}_{2} \mathrm{H}_{2}$ & 21 & -3.2 & 6.8 & 17.2 \\
$\mathrm{HCN}$ & 15 & 243.3 & 40.9 & 365.7 \\
$\mathrm{HCN}$ & 18 & 254.8 & 36.7 & 364.9 \\
$\mathrm{HCN}$ & 21 & 229.1 & 34.9 & 333.8 \\
$\mathrm{HCOOH}$ & 15 & 14.5 & 18.8 & 70.9 \\
$\mathrm{HCOOH}$ & 18 & 8.2 & 19.8 & 67.6 \\
$\mathrm{HCOOH}$ & 21 & 8.4 & 17.8 & 61.8 \\
\hline
\end{tabular}

native to GEM. The vertical transport includes parameterized subgrid-scale turbulence and deep convection. Dry deposition is included as a flux boundary condition in the vertical diffusion equation. Both in-cloud and below-cloud scavenging are considered. The original chemistry mechanism described in Kaminski et al. (2008) was expanded to include HCN loss processes (Lupu et al., 2009) and production of $\mathrm{HCOOH}$ via reactions initiated by $\mathrm{HCHO}+\mathrm{HO}_{2}$. No aerosol physics and chemistry were implemented in this version of the model. The GEM-AQ has been validated by comparison with spaceborne, airborne and balloon-borne observations (Kaminski et al., 2008).

The model run simulated the largest of the Victorian fires, the Kilmore East fire on 7 February $85 \mathrm{~km}$ north of Melbourne only. We can not definitely state that the main plumes that penetrated to the stratosphere resulted from the Kilmore East fire. However, as this fire was the largest one, it is rather probable that it caused the major part of the stratospheric plumes. The model fire distribution was taken from the Royal Commission report (Teague et al., 2010). Calculations by the PHOENIX RapidFire fire spread model (Tolhurst et al., 2008) suggest that the total heat output of the fire on 7 February was $53 \mathrm{PJ}$ (Tolhurst, 2009). Assuming a standard heat of combustion of $18.7 \mathrm{MJ} \mathrm{kg}^{-1}$ for forest fuel (Trentmann et al., 2006) and a carbon content of $0.48 \mathrm{~kg} \mathrm{C} \mathrm{kg}^{-1}$ dry fuel (van der Werf et al., 2010), we estimated a total emission of $1.4 \mathrm{TgC}$. Our estimated carbon emissions are in agreement with recently published values from the GFED3 daily database (Mu et al., 2011). Based on this amount, and by using biome-dependent emission factors (Andreae and Merlet, 2001; M. O. Andreae, personal communication, 2009), we quantified emissions for 23 pyrogenic species, all of which were included in the simulation. In particular we estimated $\mathrm{HCN}$ at $2.3 \mathrm{Gg}, \mathrm{C}_{2} \mathrm{H}_{2}$ at $0.7 \mathrm{Gg}$, and $\mathrm{HCOOH}$ at $1.0 \mathrm{Gg}$. Background emissions (yearly averaged for anthropogenic and monthly averaged for biogenic emissions and biomass burning) used in the GEM-AQ simulation are from Kaminski et al. (2008).

The model was run from 7 February to 7 March 2009. The run consisted of a simulation at $50 \mathrm{~km}$ horizontal and $\sim 300 \mathrm{~m}$ vertical resolution (middle and upper troposphere) to study the global impacts. The evolution of the pyroconvection tower could not be properly simulated due to lack of sufficient resolution to resolve convective turbulence, absence of 3-D radiative transfer and missing aerosol radiative effects (including those suggested by de Laat et al., 2012). Instead the initial plume was prescribed as a grid box column. The pyrogenic emissions were distributed between 14 and $18 \mathrm{~km}$ in order to produce the lofting of the plume into the stratosphere. The column injection was switched on for $6 \mathrm{~h}$, centered at 11:00 UT on 7 February. This choice of injection interval was constrained on the lower end by the observation of pyroconvection development in the afternoon (local time) and on the higher end by the substantial decrease in fire intensity before midnight.

With these initial conditions we obtained a reasonable correspondence between the observed and modelled plume transport in the subsequent weeks. A simulation where the 

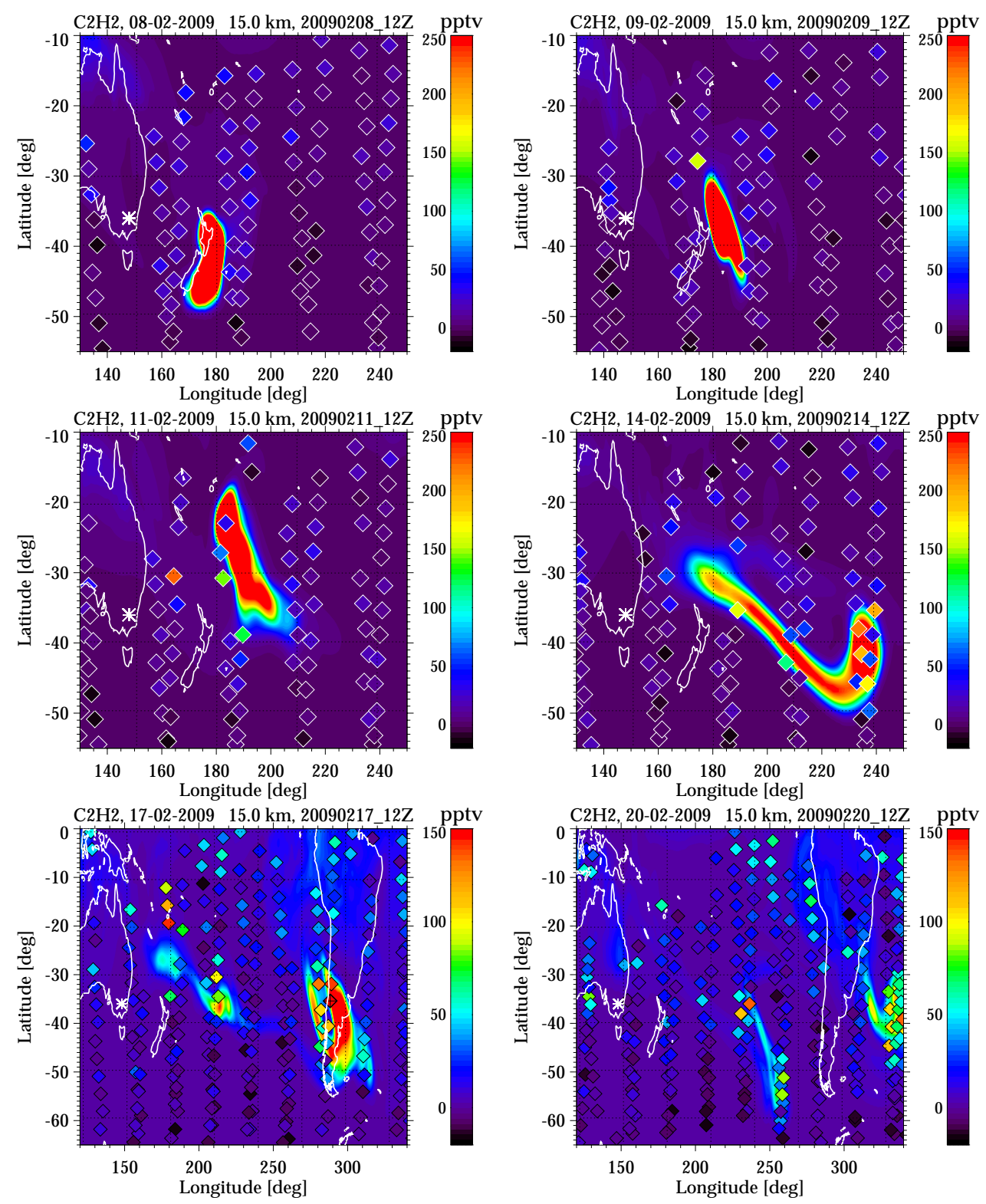

Fig. 3. MIPAS $\mathrm{C}_{2} \mathrm{H}_{2}$ data at $15 \mathrm{~km}$ altitude (diamonds), measured on 8, 9, 11, 14, 17 and 20 February 2009 (top left to bottom right). Background areas are GEM-AQ $\mathrm{C}_{2} \mathrm{H}_{2}$ model distributions for $12 \mathrm{UT}$ of the respective days. Model distributions are smoothed vertically and along-track to MIPAS resolution. Note the different map section and colour scale for the bottom panel. Red diamonds with black pluses inside indicate MIPAS VMRs higher than 250 (150) pptv, and red areas are GEM-AQ data equal to or higher than 250 (150) pptv. The white star indicates the location of the Kilmore East fire.

emissions were distributed below $8.5 \mathrm{~km}$ failed to transport tracers above $16 \mathrm{~km}$. However, it is unlikely that the Kilmore East pyroconvection only rose to $8.5 \mathrm{~km}$. Except for the resulting altitude distribution, the initial plume release details such as the lofting mechanism appear to be of secondary importance.

To enable comparison with observations, the model was re-initialized every $24 \mathrm{~h}$ with analysis data. A 6-h adjustment period was used to ingest analysis winds and temperatures without chemistry and transport of species. Chemistry and species transport were switched on for a 24 -h period following the adjustment period and using the output from the end of the previous day as input. For the investigations presented in this paper, model data with output saved every $6 \mathrm{~h}$ were available. In the Supplement we present an animation of the expansion of the model HCN 450-pptv isosurface in original resolution during the first two weeks after the outbreak of the fire. 

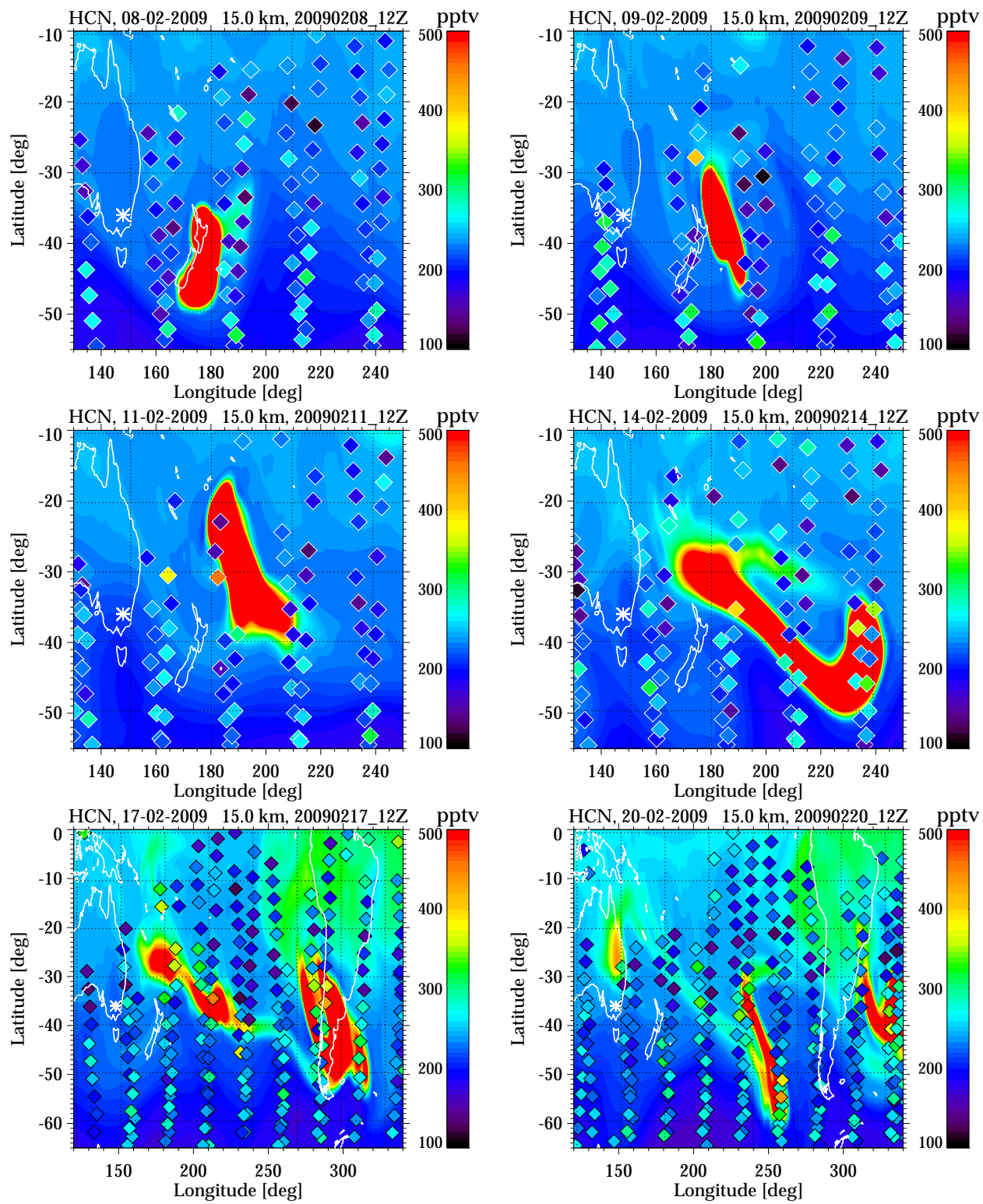

Fig. 4. Measured and modelled $\mathrm{HCN}$ at $15 \mathrm{~km}$ altitude. Model distributions are smoothed vertically and along-track to MIPAS resolution. Note the different map section for the bottom panel. For more details see Fig. 3.

\subsection{Smoothing of model data}

To compare with MIPAS data, the model fields were convolved with horizontal and vertical averaging kernels representative for the biomass burning products measured by MIPAS. For this purpose, the irregularly gridded model data were first interpolated onto a regular grid with latitudinal and longitudinal spacing of $0.5^{\circ}$ and a vertical sampling of $1 \mathrm{~km}$. Then each grid point of this field was convolved with a triangular weighting function with a vertical full width at half maximum (FWHM) of $5 \mathrm{~km}$ and a latitudinal FWHM of $300 \mathrm{~km}$. The width of the applied vertical smoothing function is the average height resolution of the different gases for the altitude region 15 to $21 \mathrm{~km}$ (cf. Sect. 2.2), and the width of the applied horizontal smoothing function is at the upper end of the horizontal averaging kernels estimated for MIPAS in von Clarmann et al. (2009). After degradation to MIPAS resolution, fine-scale structures of the original GEM-AQ distributions of course become blurred to a certain degree. 

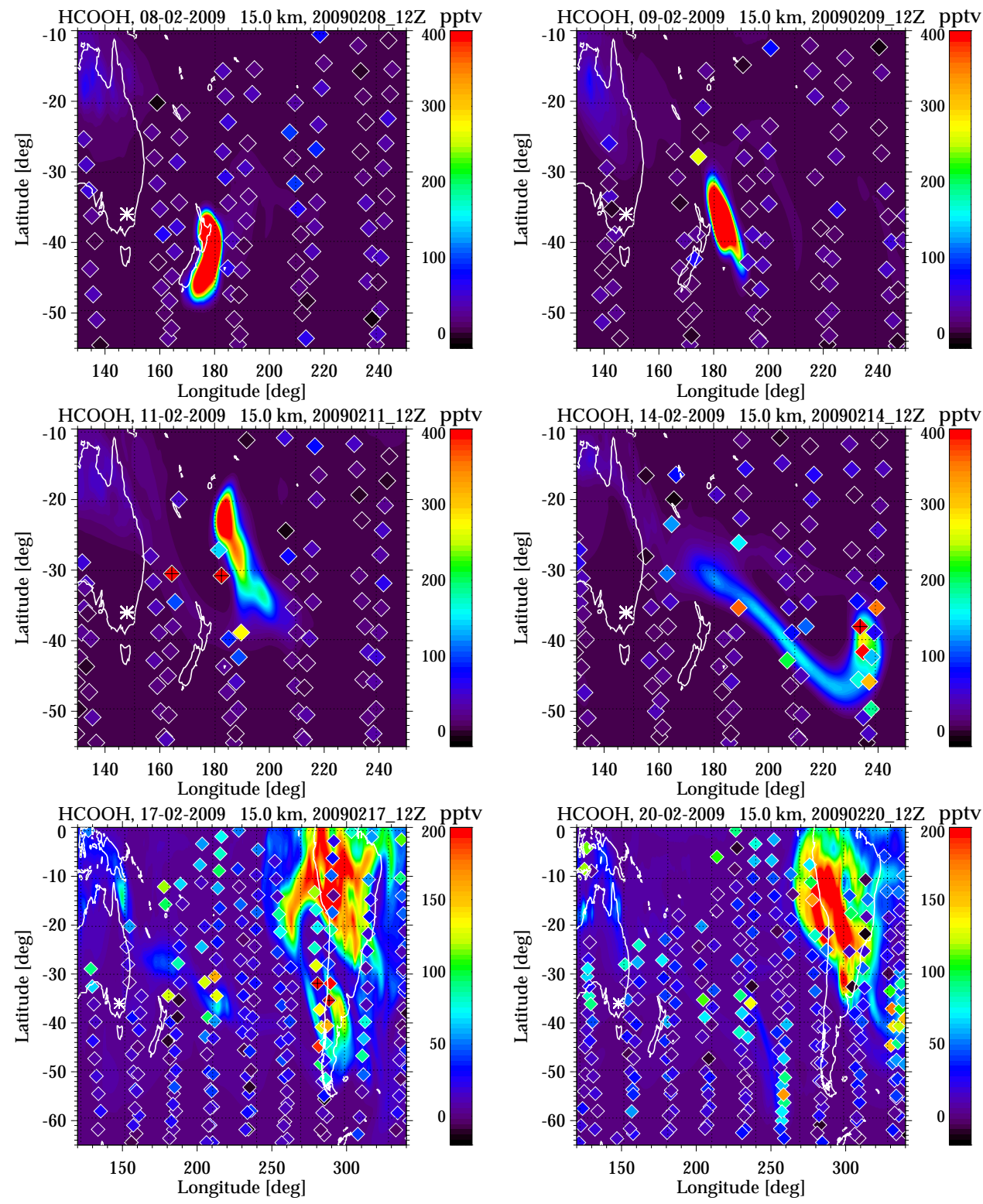

Fig. 5. Measured and modelled $\mathrm{HCOOH}$ at $15 \mathrm{~km}$ altitude. Model distributions are smoothed vertically and along-track to MIPAS resolution. Note the different map section and colour scale for the bottom panel. For more details see Fig. 3.

\section{Comparison of measured and modelled plume}

\subsection{Horizontal plume expansion at 15 and $18 \mathrm{~km}$ altitude}

In this section we discuss measured and modelled $\mathrm{C}_{2} \mathrm{H}_{2}$, $\mathrm{HCN}$ and $\mathrm{HCOOH}$ distributions of 8, 9, 11, 14, 17 and 20 February at the altitudes of $15 \mathrm{~km}$ (Figs. 3-5) and $18 \mathrm{~km}$ (Figs. 6-8). The comparison is focused on these three gases, since MIPAS data of these species exhibit a large contrast between plume and background values. The distributions are displayed at 15 and $18 \mathrm{~km}$, because after one week the plume split up into two parts, which drifted in eastward and westward direction at these altitudes. Since the MIPAS data shown are from any time of the day, the model distributions in this general overview are always from 12:00 UT. If not stated otherwise, the model data are always degraded to MIPAS resolution (cf. Sect. 3.1).

On 8 February, 12:00 UT, one day after the outbreak of the fires in southeastern Australia, the GEM-AQ plume had already been transported far in southeastward direction by strong winds and is situated above and to the east of New Zealand (Figs. 3-8, top left). Such a fast southeastward transport has also been described in de Laat et al. (2012). On this day MIPAS observed only background values at the altitudes 

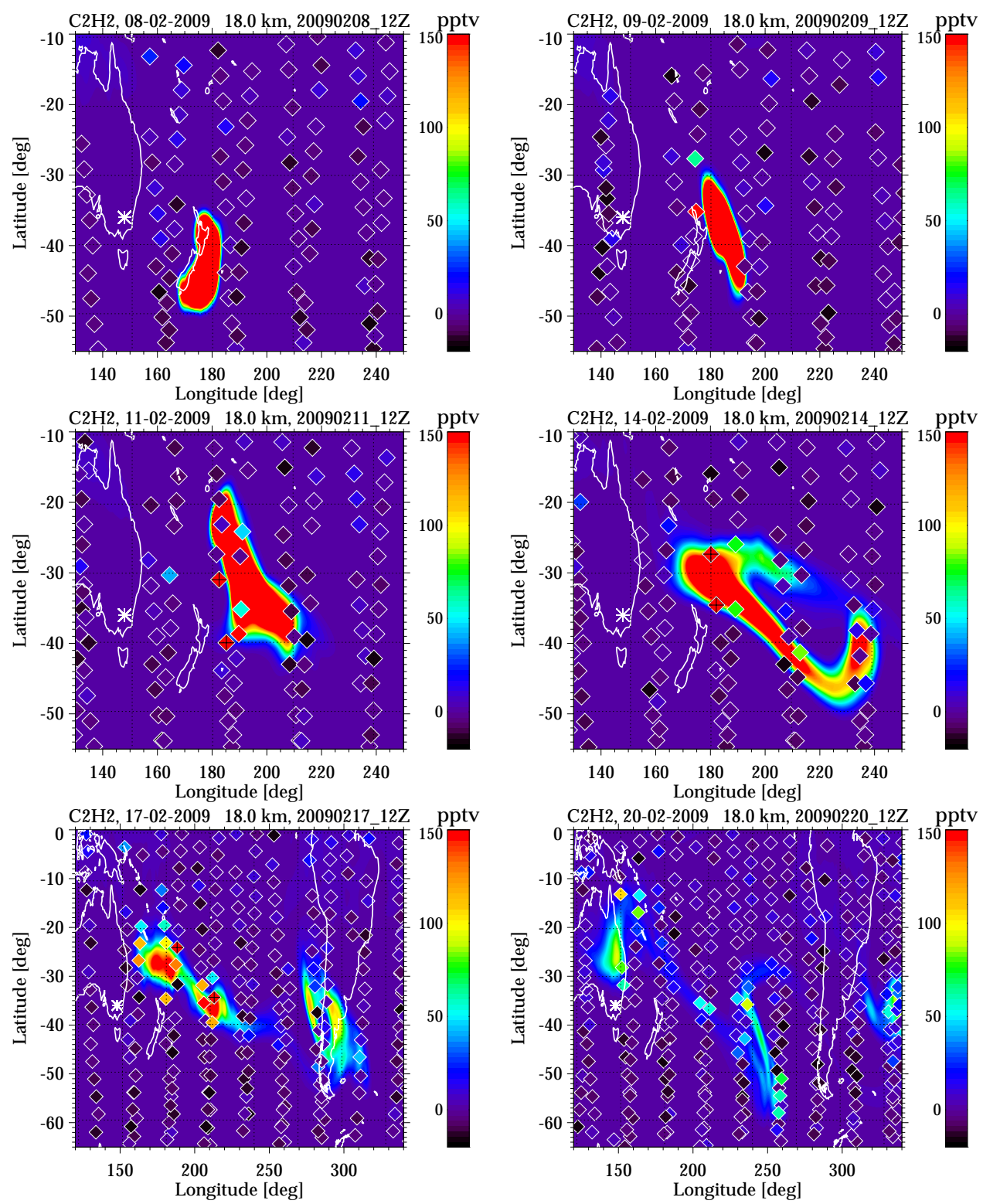

Fig. 6. Measured and modelled $\mathrm{C}_{2} \mathrm{H}_{2}$ at $18 \mathrm{~km}$ altitude. Model distributions are smoothed vertically and along-track to MIPAS resolution. Note the different map section for the bottom panel. For more details see Fig. 3.

of 15 and $18 \mathrm{~km}$, which on first view is plausible, because the 12:00 UT model plume is not covered by measurements. After temporal interpolation to the measurement times of the adjacent datapoints, the model plume did not cover any of them either (not shown). Thus, lack of measured pollutants at $15-18 \mathrm{~km}$ either reflects a sampling problem or a too high altitude of the early model plume. Before 9 February plume altitudes of $14 \mathrm{~km}$ and more had also not been observed by other satellite experiments, e.g. the Cloud-Aerosol Lidar and Infrared Pathfinder Satellite Observations (CALIPSO) satellite and the Ozone Monitoring Instrument (OMI) on the Aura satellite (de Laat et al., 2012). In Sect. 4.2 we will show that during the first days MIPAS observed enhanced $\mathrm{C}_{2} \mathrm{H}_{2}$ at the lower altitude of $12 \mathrm{~km}$ instead and compare these measurements with the model data.

On February 9 the GEM-AQ plume had moved somewhat further to the north and had slightly rotated in anticlockwise direction. On this day MIPAS measured the first strongly enhanced amounts of pollutants (e.g. $\mathrm{C}_{2} \mathrm{H}_{2}$ amounts of up to $153 \mathrm{pptv})$ in the upper troposphere and lower stratosphere (UTLS) at one $(15 \mathrm{~km})$ or two $(18 \mathrm{~km})$ geolocations only slightly north- and westward of the model plume (Figs. 3-8, top right). These measurements were performed later around 22:25 UT, but at this time the northwestern edge of the 

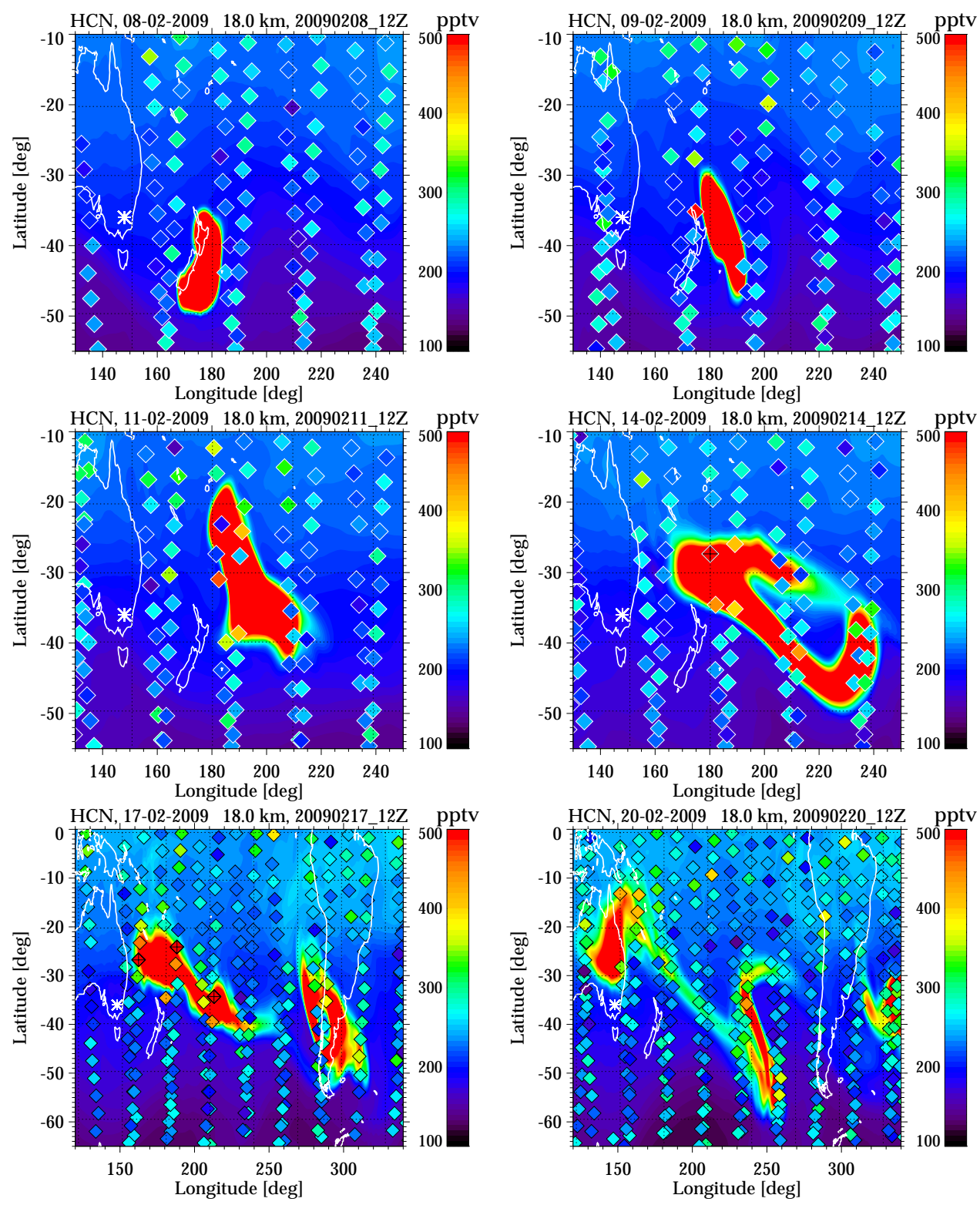

Fig. 7. Measured and modelled HCN at $18 \mathrm{~km}$ altitude. Model distributions are smoothed vertically and along-track to MIPAS resolution. Note the different map section for the bottom panel. For more details see Fig. 3.

model plume had not moved very much. The southern part of the 12:00 UT plume is missed by measurements of MIPAS, which explains observation of background values only in this region. There was also no overlap with datapoints after temporal interpolation of the model plume to the measurement times of the adjacent MIPAS geolocations.

During the following days the model plume drifted further to the north, where it experienced a certain stagnation. On 11 February MIPAS observed considerably enhanced $\mathrm{C}_{2} \mathrm{H}_{2}, \mathrm{HCN}$ and $\mathrm{HCOOH}$ values at 3-6 coincident geolocations in reasonable accordance with the model plume, but slightly displaced to the south-west (Figs. 3-8, middle left).
One geolocation with enhanced measured pollutants at $31^{\circ} \mathrm{S}$, $165^{\circ} \mathrm{E}$ is considerably east of the 12:00 UT plume. This measurement was performed much later at 23:02 UT, but there is no better agreement with the time-interpolated model plume. An eastward movement of the GEM-AQ plume does not occur until 12 February.

On 13 February the leading edge of the model plume started to move rapidly in southeastern direction. Thus, on 14 February the plume was strongly elongated. At $15 \mathrm{~km}$ altitude its major part had moved far southeastward, whereas its western end was still northward of New Zealand (Figs. 35, middle right). At $18 \mathrm{~km}$ the model plume has a similar 

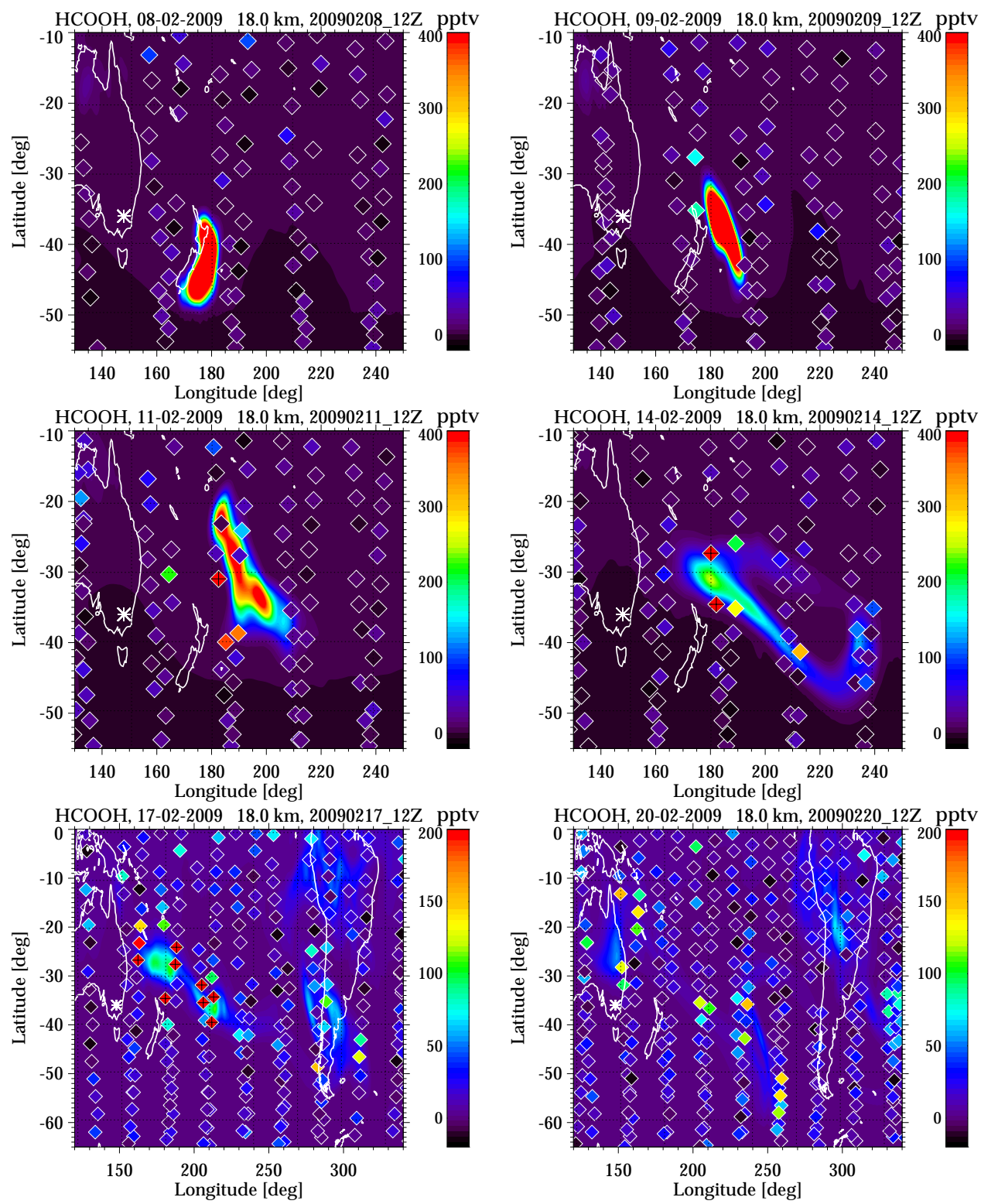

Fig. 8. Measured and modelled $\mathrm{HCOOH}$ at $18 \mathrm{~km}$ altitude. Model distributions are smoothed vertically and along-track to MIPAS resolution. Note the different map section and colour scale for the bottom panel. For more details see Fig. 3.

shape, but at this height its western part is more strongly pronounced (Figs. 6-8, middle right). There is good agreement with $\mathrm{C}_{2} \mathrm{H}_{2}$ and $\mathrm{HCOOH}$ data of MIPAS at $15 \mathrm{~km}$ altitude, whereby enhanced MIPAS values are concentrated in the south-eastern part of the model plume. At $18 \mathrm{~km}$, strongly enhanced amounts of pollutants were measured at the northwestern end and in the middle section of the plume only, but not at its eastern end. This indicates a somewhat too high altitude of the model plume in this region.

On 17 February the model plume had nearly split into three parts. At $15 \mathrm{~km}$ altitude the major part is located above southern South America. This is in good agreement with MI-
PAS, which also measured enhanced amounts of pollutants at $15 \mathrm{~km}$ altitude in this region (Figs. 3-5, bottom left). According both to the measurements and to the model, there is a second part of the plume at $210^{\circ} \mathrm{E}$ over the Pacific. Further, MIPAS observed a third region of enhanced pollution extending from the north of New Zealand into the tropics, corresponding to a model plume relic mainly north of New Zealand. At $18 \mathrm{~km}$ altitude there are generally more strongly enhanced amounts and wider areas of measured and modelled pollutants north- and eastward of New Zealand than at $15 \mathrm{~km}$, which are in very good agreement. At this altitude the model distributions also show a plume above southern 

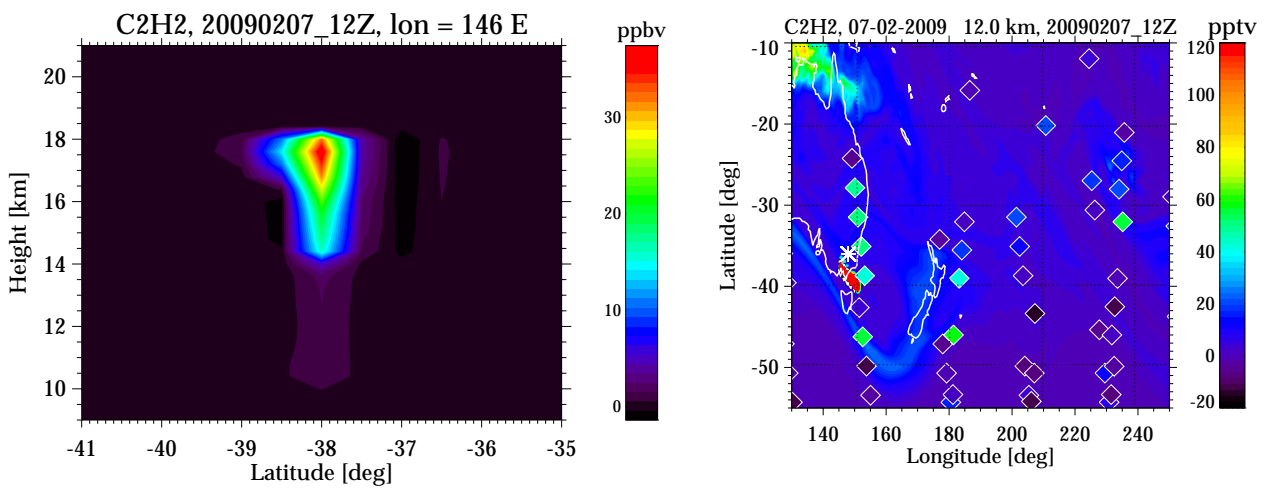

Fig. 9. Left: latitudinal cross section at $146^{\circ} \mathrm{E}$ through the GEM-AQ $\mathrm{C}_{2} \mathrm{H}_{2}$ model plume from 7 February 2009, 12:00 UT, in original resolution. Right: MIPAS $\mathrm{C}_{2} \mathrm{H}_{2}$ data at $12 \mathrm{~km}$ altitude (diamonds) from 7 February. The background area is the GEM-AQ $\mathrm{C}_{2} \mathrm{H}_{2}$ model distribution of 12:00 UT in original resolution. The white star indicates the location of the Kilmore East fire.

South America, whereas MIPAS measured only moderately enhanced amounts (Figs. 6-8, bottom left). Again, this indicates a somewhat too high model plume in this area.

According to the GEM-AQ data, the maximum above South America had been transported further eastward to the South Atlantic on 20 February (Figs. 3-8, bottom right). This is confirmed by MIPAS $\mathrm{C}_{2} \mathrm{H}_{2}$ and $\mathrm{HCN}$ at $15 \mathrm{~km}$ altitude, but at $18 \mathrm{~km}$ enhanced amounts of pollutants were not measured above the Atlantic. Further, both datasets exhibit enhanced values at $15 \mathrm{~km}$ and $18 \mathrm{~km}$ altitude in a long north-southward stripe over the South Pacific, which is a second eastward travelling plume relic. At $18 \mathrm{~km}$ altitude the western part of the plume is more strongly pronounced. Here the model plume is situated above northeast Australia. There are no observations available from the center of the model plume, but MIPAS also measured enhanced amounts of pollutants at its northeastern edge.

In addition to the Australian plume, the modelled $\mathrm{HCOOH}$ distribution exhibits an extended plume at $15 \mathrm{~km}$ altitude above tropical South America. This is due to the rapid isoprene oxidation by $\mathrm{OH}$ and the breakdown reaction scheme, which produces $\mathrm{HCOOH}$ in the GEM-AQ. For example, on 17 February modelled $\mathrm{HCOOH}$ amounts at $15 \mathrm{~km}$ over tropical South America are higher than inside the Australian plume, whereas MIPAS measured strongly enhanced values in the Australian plume only. Tropical MIPAS HCOOH data are generally lower than those measured in the Australian plume region. Elevated $\mathrm{HCOOH}$ amounts around tropical South America were rather observed at $12 \mathrm{~km}$ altitude by MIPAS. Obviously the model convective scheme (Kain-Fritsch) causes too much overshooting into the tropical transition layer (TTL).

In summary, practically all geolocations of enhanced measured $\mathrm{C}_{2} \mathrm{H}_{2}, \mathrm{HCN}$ and $\mathrm{HCOOH}$ are identical. This is as expected, reflecting the fact that the upper tropospheric lifetime of each of the species is $1-3$ weeks $\left(\mathrm{HCOOH}, \mathrm{C}_{2} \mathrm{H}_{2}\right.$ ) or longer $(\mathrm{HCN})$, but it also illustrates the data quality of
MIPAS. Further, there is generally good agreement in the location of the measured and the modelled plume for most of the days presented.

\subsection{The early plume at $12 \mathrm{~km}$}

For the reasons outlined in Sect. 3, the GEM-AQ plume was directly injected into the altitude region $14-18 \mathrm{~km}$, with emissions distributed over 6 h centered on 7 February 2009, 11:00 UT. Figure 9 (left) shows a latitudinal cross section of the initial model plume from 7 February, 12:00 UT, in original resolution, containing $\mathrm{C}_{2} \mathrm{H}_{2}$ amounts of more than 30 ppbv. In agreement with other satellite observations (cf. Sect. 4.1), MIPAS measured only background $\mathrm{C}_{2} \mathrm{H}_{2}$ amounts at altitudes of $14-18 \mathrm{~km}$ on an overpass, which, though it did not exactly cover the model plume, was spatially and temporally $(\sim 12: 16 \mathrm{UT})$ very close to the fire region. On the other hand, slightly enhanced values of up to $50 \mathrm{pptv}$ were observed at $12 \mathrm{~km}$ altitude (Fig. 9, right).

On 8 February MIPAS also measured only background amounts of pollutants between 15 and $18 \mathrm{~km}$, but enhanced values at the altitude of $12 \mathrm{~km}$ instead, e.g. $\mathrm{C}_{2} \mathrm{H}_{2}$ amounts of up to $110 \mathrm{pptv}$ around 10:00 UT and 21:15 UT to the east and northeast of New Zealand. In good agreement, the GEMAQ plume, interpolated to the respective times, subsequently covers these datapoints or is very close to them (Fig. 10, top row). In these diagrams the plume is displayed in original resolution to avoid predominance by its much stronger part at higher altitudes. A longitudinal cross section at $44^{\circ} \mathrm{S}$ through the plume, interpolated to 10:01 UT and also in original resolution, shows that like on 7 February its major part is between altitudes of 14 and $18 \mathrm{~km}$ (Fig. 10, bottom left). The MIPAS scan of 10:01 UT at $185^{\circ} \mathrm{E}$ just misses the upper part of the model plume and detects enhanced $\mathrm{C}_{2} \mathrm{H}_{2}$ at $12 \mathrm{~km}$ altitude (diamond) only, which corresponds exactly with a weak model filament. In summary, due to non-coverage of the central part of the model plume of 8 February, MIPAS 

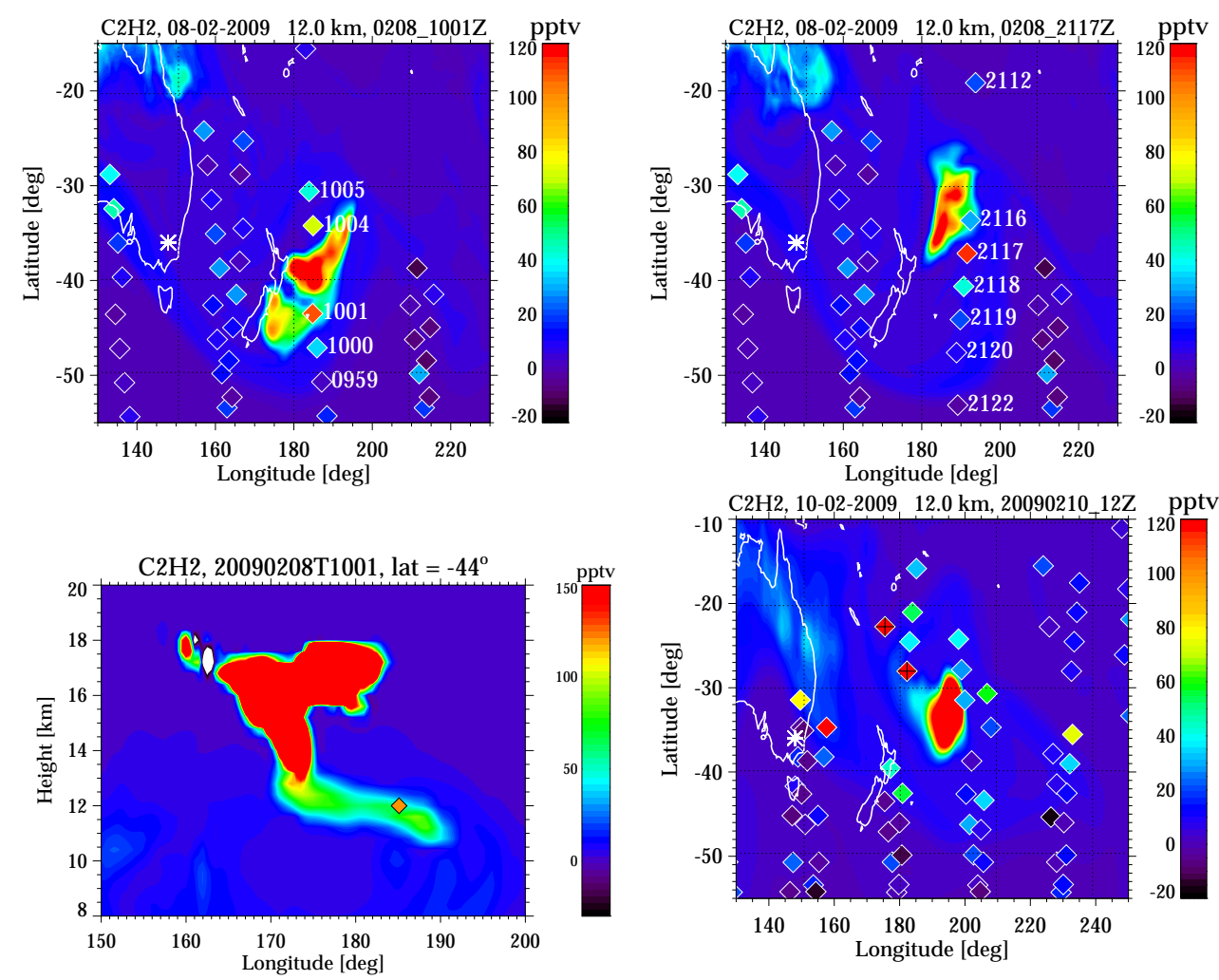

Fig. 10. Top: measured and modelled $\mathrm{C}_{2} \mathrm{H}_{2}$ distributions of 8 February at $12 \mathrm{~km}$ altitude. The model distribution is in original resolution and interpolated to 10:01 UT (right) and to 21:17 UT (left). The white numbers are the MIPAS measurement times in UT. Bottom left: longitudinal cross section at $44^{\circ} \mathrm{S}$ through the model plume from 8 February, 10:01 UT, in original resolution. The diamond at $185^{\circ} \mathrm{E}$ is the MIPAS measurement from 10:01 UT. Bottom right: measured and modelled $\mathrm{C}_{2} \mathrm{H}_{2}$ distributions of 10 February at $12 \mathrm{~km}$ altitude. The model distribution is from 12:00 UT and in original resolution.

can neither confirm nor refute its height of $14-18 \mathrm{~km}$. However, as mentioned in Sect. 4.1, plume heights of more than $14 \mathrm{~km}$ were also not measured by CALIPSO and OMI on this day. On the other hand, the locations of $\mathrm{C}_{2} \mathrm{H}_{2}$ measurements at $12 \mathrm{~km}$ are confirmed by the weak model plume at lower altitudes. At this altitude the modelled volume mixing ratios are lower than the measured $\mathrm{C}_{2} \mathrm{H}_{2}$ amounts even in original resolution.

Rather widespread plume dispersion at $12 \mathrm{~km}$ altitude with $\mathrm{C}_{2} \mathrm{H}_{2}$ amounts of up to 325 pptv was also observed by MIPAS on 10 February (Fig. 10, bottom right). The model field in original resolution exhibits a rather similar distribution, but contains fewer amounts of $\mathrm{C}_{2} \mathrm{H}_{2}$. Thus, comparison of measured and modelled $\mathrm{C}_{2} \mathrm{H}_{2}$ of 8 and 10 February at $12 \mathrm{~km}$ indicates that during the first days after the outbreak of the fire a larger portion of pollutants was released at lower altitudes than modelled by the GEM-AQ.

\subsection{Measured and modelled volume mixing ratios}

On the first three of the days presented in Figs. 3-8, the GEM-AQ volume mixing ratios are much higher than those of MIPAS although they were smoothed with the MIPAS averaging kernels. For example, smoothed model $\mathrm{C}_{2} \mathrm{H}_{2}$ amounts of 9 February are up to $2.46 \mathrm{ppbv}$ at $15 \mathrm{~km}$ altitude, whereas the highest measured $\mathrm{C}_{2} \mathrm{H}_{2}$ amount at this height is $\sim 0.15$ ppbv only (Table 2 ). However, if the model plume exactly reflects the location of the "real" pollutants, MIPAS never sounded the central part of the plume on these days, which would explain measurement of lower mixing ratios. But, as outlined above, direct injection of nearly the whole simulated plume into the height region of $14-18 \mathrm{~km}$ obviously led to too high model values at these altitudes at least to a certain degree. MIPAS data show that a significant part of the plume is released at lower altitudes around $12 \mathrm{~km}$. Another possible reason for the discrepancy is the assumption of too large fire emissions for the model inventory. Too weak mixing of the model plume into the surrounding background obviously can be excluded from comparison with the measurements. On 14, 17 and 20 February, when MIPAS also sounded the central part of the model plume, the $\mathrm{C}_{2} \mathrm{H}_{2}$ mixing ratios especially at 15 and $18 \mathrm{~km}$ agree much better (Table 2). 
Table 2. Maximum MIPAS and GEM-AQ $\mathrm{C}_{2} \mathrm{H}_{2}$ amounts of selected days in the area $53-20^{\circ} \mathrm{S}, 120^{\circ} \mathrm{E}-20^{\circ} \mathrm{W}$.

\begin{tabular}{lcrr}
\hline Day & $\begin{array}{c}\text { Height } \\
{[\mathrm{km}]}\end{array}$ & $\begin{array}{r}\text { MIPAS } \\
\text { max VMR } \\
\text { [pptv] }\end{array}$ & $\begin{array}{r}\text { GEM-AQ } \\
\text { max VMR } \\
\text { [pptv] }\end{array}$ \\
\hline 20090208 & 12 & 111.7 & 992.6 \\
& 15 & 43.1 & 2622.4 \\
& 18 & 17.3 & 1680.8 \\
& 21 & 16.4 & 482.8 \\
\hline 20090209 & 12 & 58.0 & 767.4 \\
& 15 & 152.7 & 2459.5 \\
& 18 & 142.6 & 2471.2 \\
& 21 & 26.8 & 777.7 \\
\hline 20090210 & 12 & 325.48 & 572.1 \\
& 15 & 109.49 & 1740.6 \\
& 18 & 69.92 & 1540.5 \\
& 21 & 23.9 & 382.1 \\
\hline 20090211 & 12 & 106.5 & 384.3 \\
& 15 & 222.5 & 1153.2 \\
& 18 & 183.0 & 786.5 \\
& 21 & 45.3 & 328.2 \\
\hline 20090214 & 12 & 120.9 & 181.3 \\
& 15 & 214.8 & 460.8 \\
& 18 & 279.7 & 470.6 \\
& 21 & 66.9 & 237.4 \\
\hline & 12 & 79.1 & 137.6 \\
& 15 & 222.7 & 237.9 \\
& 18 & 201.8 & 221.9 \\
& 12 & 60.3 & 147.4 \\
\hline \multirow{2}{*}{20090220} & 12 & 105.9 & 63.7 \\
& 15 & 131.5 & 149.4 \\
& & 35.3 & 117.2 \\
& & & 103.5 \\
\hline
\end{tabular}

Modelled $\mathrm{HCN}$ and $\mathrm{HCOOH}$ amounts are also much higher than the measurements during the first days after the fire. For example, on 9 February modelled HCN volume mixing ratios (VMRs) at $18 \mathrm{~km}$ are up to more than $10 \mathrm{ppbv}$, but measured HCN VMRs up to 0.5 ppbv only. On 20 February the difference became smaller, but the maximum modelled HCN amounts are still a factor of 3 higher than the measurements. Modelled $\mathrm{HCOOH}$ decreases more rapidly than $\mathrm{C}_{2} \mathrm{H}_{2}$ and $\mathrm{HCN}$ and after one week is lower than measured $\mathrm{HCOOH}$.

\subsection{Plume altitude}

\subsubsection{1 and 17 February 2009}

11 February is the first day well suited for comparison of measured and modelled altitudes of the main plume, because on this day MIPAS measured strongly enhanced amounts of pollutants at several geolocations. Figure 11 (left) shows a cross section in original resolution through the central part of the GEM-AQ plume, which exhibits a significant latitudinal decrease from $\sim 18.5 \mathrm{~km}$ at $38^{\circ} \mathrm{S}$ to $16 \mathrm{~km}$ at its northern end. A similar latitudinal decrease of plume altitudes is also visible in MIPAS $\mathrm{C}_{2} \mathrm{H}_{2}$ profiles, but at somewhat lower altitudes (Fig. 11, right). Three profiles measured in the region of the southern part of the model plume have maxima of 150200 pptv at $17 \mathrm{~km}$ altitude and three other profiles measured further north at altitudes between 13 and $16 \mathrm{~km}$ or below. Thus, four days after the outbreak of the fires the measured plume is clearly located in the UTLS region. The slightly enhanced $\mathrm{C}_{2} \mathrm{H}_{2}$ profiles with maxima at $12 \mathrm{~km}$ altitude were obtained between New Zealand and Australia. The profiles of 17 February already presented in Fig. 1 also show measured plume altitudes of $17-18 \mathrm{~km}$ for the part of the plume north-east of New Zealand.

\subsubsection{Time series}

Figure 12 displays a time series of average plume altitudes, derived from MIPAS profiles of enhanced $\mathrm{C}_{2} \mathrm{H}_{2}$, in comparison with model plume altitudes, whereby plume altitudes are defined as the heights of the VMR maxima. Except for the first three days, only measured profiles with a local maximum in the upper troposphere or lower stratosphere were taken into account. Because of the split-up of the plume after 14 February, the presentation consists of three curves each for measured and modelled altitudes. Between 7 and 9 February MIPAS observed plume altitudes of 10 to $12 \mathrm{~km}$ only, except for two profiles from 9 February, which are truncated at 15 and $17 \mathrm{~km}$ (no local maxima). Measured plume altitudes reached $14.5 \mathrm{~km}$ on 10 February and $15-17 \mathrm{~km}$ on 11 February. The first eastward transported plume fragment observed by MIPAS (solid red curve) was centered at $15 \mathrm{~km}$ and the second fragment (solid blue curve) at $16.5 \mathrm{~km}$ altitude. After 17 February, the upper part of the plume was transported westward. Measured altitudes of this part of the plume reached $18 \mathrm{~km}$ on 19 February and more than $19 \mathrm{~km}$ at the end of the month (solid black curve). Contrary to MIPAS, modelled plume altitudes are between 17.5 and $18 \mathrm{~km}$ immediately after the outbreak of the fires. However, after 10 February model plume altitudes (dashed curves) agree well with the measured plume heights. Modelled heights of the westward drifting plume are about $1 \mathrm{~km}$ higher than the measured altitudes, but they show a similar increase.

\subsubsection{Intrusion into the stratosphere}

For a spatial overview of measured plume altitudes, Fig. 13 shows the locations and geometrical heights of the maxima of measured $\mathrm{C}_{2} \mathrm{H}_{2}$ profiles. Only local maxima above 50 pptv are plotted. First unique sounding of the plume in the UTLS region $(17 \mathrm{~km})$ on 11 February occurred east and north of New Zealand (top left). On 17 and 18 February, plume 

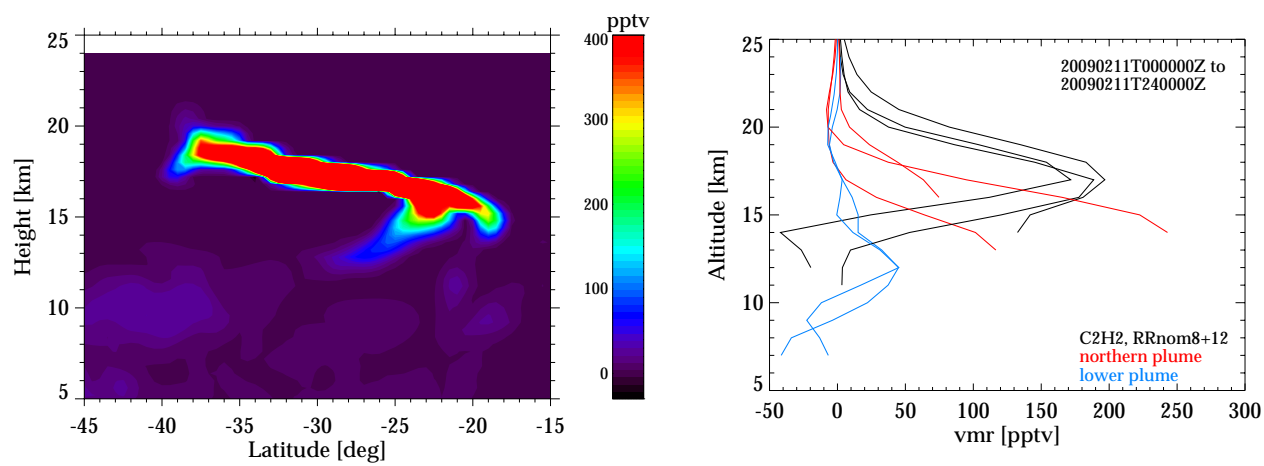

Fig. 11. Left: latitudinal cross section through the model plume of 11 February at $172^{\circ} \mathrm{W}$ in original resolution. Right: $\mathrm{C}_{2} \mathrm{H}_{2}$ profiles measured on 11 February 2009, inside the southern (black) and northern part of the plume (red), and in weaker parts of the lower plume (blue).

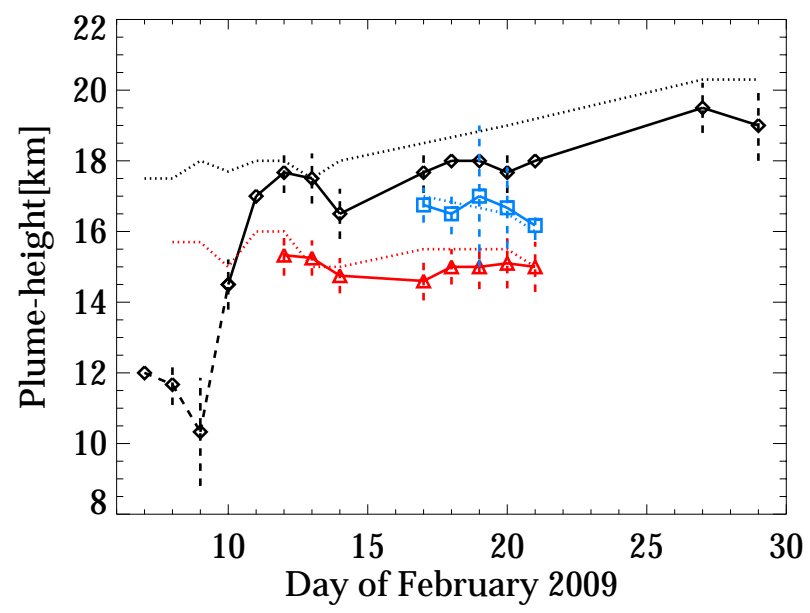

Fig. 12. Lines with symbols: average height of the biomass burning plume caused by the Australian bushfires, derived from MIPAS $\mathrm{C}_{2} \mathrm{H}_{2}$ profiles. The black curve represents weaker and low parts of the plume sounded between 7 and 9 February (dashed) and the southern part of the central plume sounded thereafter (solid), which travelled westward after 17 February. The red and blue curves represent the lower parts of the central plume, which were subsequently transported eastward after 14 February. Dotted lines: respective GEM-AQ plume heights.

altitudes of $17-18 \mathrm{~km}$ were observed north of New Zealand and of 16-17 km east of New Zealand. The plume over southern South America on 17 February is centered at altitudes of 14-15 km, while the second fragment transported towards southern South America (21 February) is located at $17 \mathrm{~km}$.

Plume altitudes of $17 \mathrm{~km}$ and more observed only some days after the Australian bushfire event indicate fast transport of the pollutants into the lower stratosphere. To exclude just apparent penetration into the stratosphere caused by smearing effects due to the restricted vertical resolution of biomass burning products observed by MIPAS $(\sim 5 \mathrm{~km}$ at these al- titudes), we checked the measured $\mathrm{C}_{2} \mathrm{H}_{2}$ profiles for maxima above the tropopause. The tropopause height was derived from the MIPAS temperature profile using the definition of the World Meteorological Organization for thermal tropopause. The underlined maxima in Fig. 13 are situated $1 \mathrm{~km}$ or more above the tropopause and thus identified as stratospheric. On 11 February (top left) there are two datapoints east of New Zealand indicating stratospheric $\mathrm{C}_{2} \mathrm{H}_{2}$ at 17 and $18 \mathrm{~km}$ altitude. The largest clusters of stratospheric $\mathrm{C}_{2} \mathrm{H}_{2}$ were observed north- and eastward of New Zealand on 17 and 18 February. This is in good agreement with the observations of Pumphrey et al. (2011). Profiles of 17 February including the tropopause height are presented in Fig. 1. On 21 February MIPAS additionally observed stratospheric $\mathrm{C}_{2} \mathrm{H}_{2}$ at higher latitudes westward of the southern end of South America, which is the second eastward travelling part of the plume.

\subsection{Westward drift of the stratospheric plume}

The further history of the stratospheric pollutants observed northward of New Zealand on 17 February is illustrated by $\mathrm{HCN}$ at $21 \mathrm{~km}$ altitude (Fig. 14). In good spatial accordance with the westward-moving model plume, enhanced HCN was measured above central Australia on 21 February, at the Australian west coast on 24 February and above the central Indian Ocean on 27 February. The observed westward transport in the tropical latitude band is caused by the westerly phase of the quasi-biennial oscillation (QBO) during spring 2009 (Siddaway and Petelina, 2011). On 1 March, measured and modelled pollutants had reached the southern African east coast. MIPAS still measured high HCN of about 500 pptv further west above central Africa on 6 March, whereas the remains of the model plume are rather diluted. As already outlined in Sect. 1, these MIPAS observations are in compliance with MLS CO data (Pumphrey et al., 2011) and with measurements of the OSIRIS instrument on the Odin satellite, which observed lower stratospheric smoke 

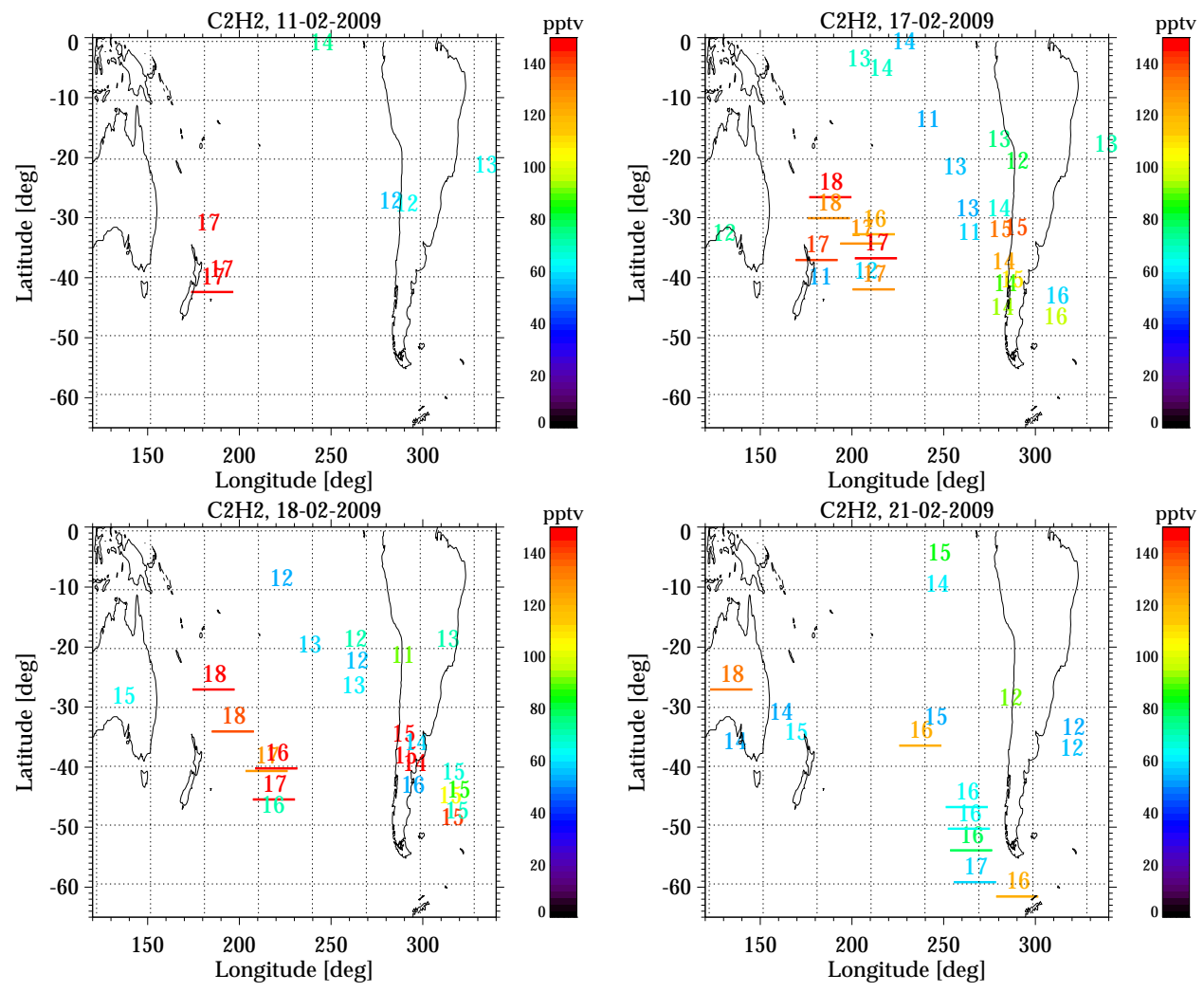

Fig. 13. Geometrical height (in km, denoted by numbers) of maxima of measured $\mathrm{C}_{2} \mathrm{H}_{2}$ profiles from $11,17,18$, and 20 February 2009 (top left to bottom right). Volume mixing ratios are colour coded, and only maxima above 50 pptv are presented. Maxima, which are $1 \mathrm{~km}$ or more above the tropopause, derived from MIPAS temperature profiles, are underlined.

particles travelling westward over Australia and the Indian Ocean (Siddaway and Petelina, 2011).

\subsection{Plume aging}

The Australian bushfire plume was a very isolated event of quasi-punctual emissions into the undisturbed upper tropospheric and lower stratospheric background. The expansion of the plume was observable over timescales of weeks. This offers an excellent opportunity to study enhancement ratios and the temporal change of plume composition.

The emission ratio of a certain biomass burning gas is defined as the ratio of the excess concentration of this gas in a fresh plume (elevated minus background concentration) and the excess concentration of a simultaneously measured reference gas. Commonly $\mathrm{CO}$ as one of the major combustion products is used as reference. Emission ratios are characterised by the material burned and thus can give information on the kind of fires that caused the plume (e.g. savanna or boreal fires, smoldering or flaming combustion). Since the ratio of excess concentrations generally changes during plume aging due to chemical processing, the term "enhancement ratio" (Akagi et al., 2011) is also used as a more general concept. Time series of enhancement ratios of pollutants with different atmospheric lifetimes give information on plume aging. On the other hand, they can be used to estimate the lifetime of pollutants.

Since correlations with MIPAS CO exhibit a large scatter, we correlated $\mathrm{C}_{2} \mathrm{H}_{2}$ and $\mathrm{HCOOH}$ with $\mathrm{HCN}$ instead and calculated enhancement ratios from the slope of fitted regression lines. We used HCN as reference gas because of its long tropospheric lifetime of about 160 days (Li et al., 2003). The datasets taken into account cover the Southern Hemisphere between the Equator and $60^{\circ} \mathrm{S}$ and the altitude range 17$21 \mathrm{~km}$. Further, a plume filter was applied which allowed for 17-21 km profile sections with $\mathrm{C}_{2} \mathrm{H}_{2}$ amounts of more than 50 pptv at $18 \mathrm{~km}$ only. In the chosen altitude range, the vertical resolution of measured $\mathrm{HCN}$ is about $1 \mathrm{~km}$ lower than that of $\mathrm{C}_{2} \mathrm{H}_{2}$ and of $\mathrm{HCOOH}$. Therefore the $\mathrm{C}_{2} \mathrm{H}_{2}$ and $\mathrm{HCOOH}$ data were degraded to $\mathrm{HCN}$ resolution by smoothing with Gaussians prior to the regression analysis. A regression analysis taking into account errors in $\mathrm{y}$ - as well as in $\mathrm{x}$-direction was applied (Leng et al., 2007). To study the temporal evolution, this analysis was performed for consecutive time periods of 7 and 3 days, respectively, starting on 9 February.

For analysis of the respective model correlations, the original non-degraded datasets were used. Since the model correlations are very compact, the standard regression analysis 

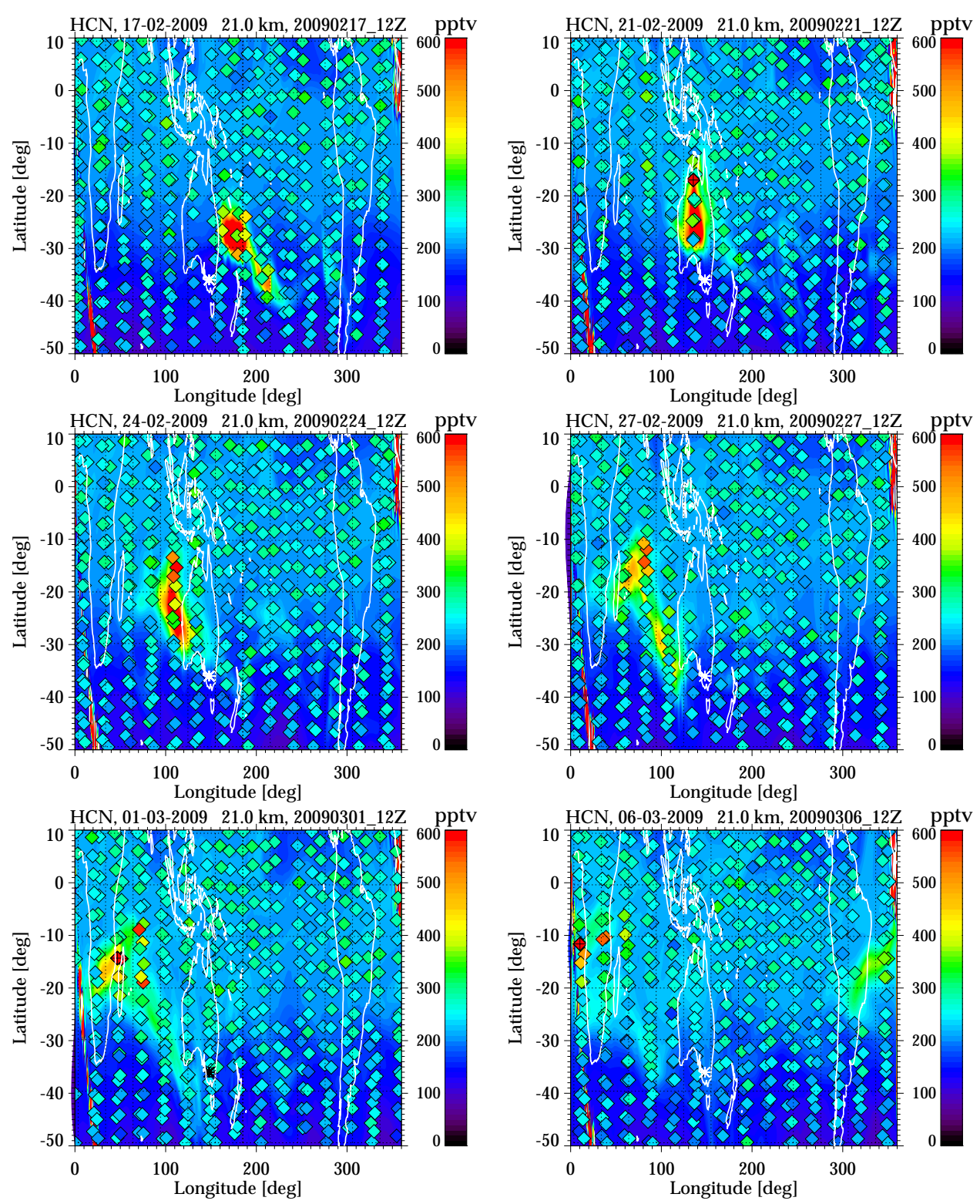

Fig. 14. MIPAS HCN data (diamonds) at $21 \mathrm{~km}$ altitude, measured on 17, 21, 24, 27 February and on 1 and 6 March 2009. Background areas are GEM-AQ HCN model distributions for 12:00 UT of the respective days. Model distributions are smoothed vertically and along-track to MIPAS resolution. Red diamonds with black pluses inside indicate MIPAS VMRs higher than 600 pptv.

was performed for 1-day temporal bins starting on 7 February and model levels $4-11$, which approximately corresponds to the altitudes of $17-21 \mathrm{~km}$.

Figure 15 (top) shows the correlation of measured $\mathrm{C}_{2} \mathrm{H}_{2}$ and HCN for 9-15 February (left) and 16-22 February 2009 (right). Due to the considerably longer lifetime of HCN, the enhancement ratio (slope of the regression lines) decreases from 0.76 to 0.45 . During the same time period, the $\mathrm{HCOOH} / \mathrm{HCN}$ enhancement ratio decreases even more strongly from 2.16 to 0.92 (Fig. 15, bottom), indicating a faster reduction of elevated $\mathrm{HCOOH}$. The enhancement ra- tios of the first time period can also be considered as lower estimates of the respective emission ratios. The GEM-AQ $\mathrm{C}_{2} \mathrm{H}_{2} / \mathrm{HCN}$ and $\mathrm{HCOOH} / \mathrm{HCN}$ emission ratios of 7 February are 0.33 and 0.25 only (cf. Fig. 16). The model ratio for $\mathrm{C}_{2} \mathrm{H}_{2} / \mathrm{HCN}$ is based on the latest best estimate for emission factors of M. O. Andreae (personal communication, 2009). The $\mathrm{C}_{2} \mathrm{H}_{2} / \mathrm{HCN}$ emission ratios derived from relevant publications (Yokelson et al., 2003, 2008; Akagi et al., 2011) generally vary between 0.25 and 0.9 . The model $\mathrm{HCOOH}$ amounts result from emission factors of Akagi et al. (2011). Other values derived from publications vary between 0.25 

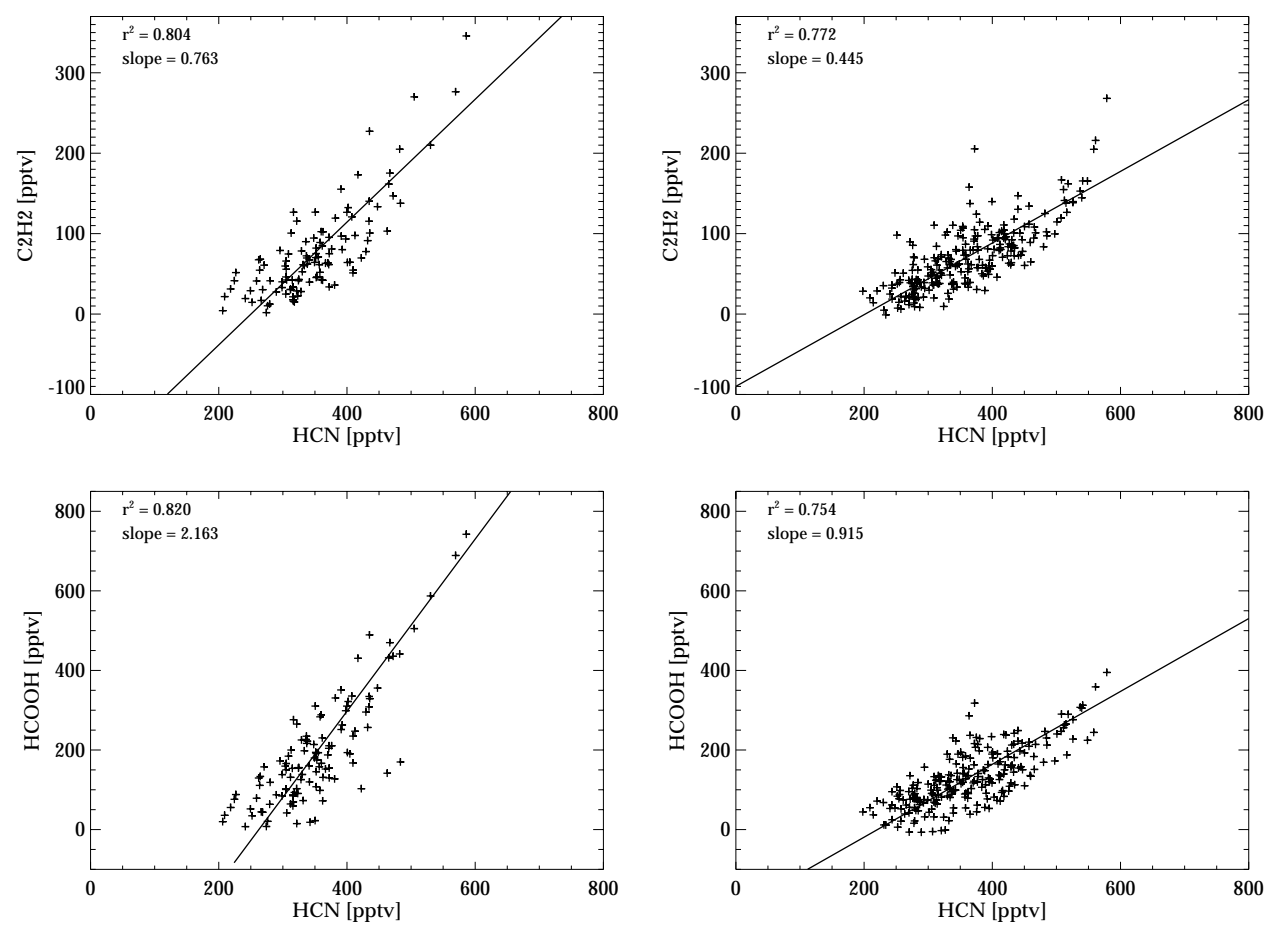

Fig. 15. Top: southern hemispheric $\left(60^{\circ} \mathrm{S}\right.$ to Equator) enhanced MIPAS $\mathrm{C}_{2} \mathrm{H}_{2}$ data plotted versus enhanced MIPAS HCN data of the time periods 9 to 15 February 2009 (left) and 16 to 22 February 2009 (right), along with fitted regression lines. Data are from the altitude region $17-21 \mathrm{~km}$ and converted to identical vertical resolution; $r^{2}$ and slope are the correlation coefficients and slopes of the regression lines. Bottom: same as top panel, but for MIPAS $\mathrm{HCOOH}$ versus $\mathrm{HCN}$ data.

and 1.49 (Yokelson et al., 2003, 2008) and 1.68 (Goode et al., 2000). Thus the MIPAS $\mathrm{C}_{2} \mathrm{H}_{2} / \mathrm{HCN}$ enhancement ratios are in the range of literature values, whereas the initial $\mathrm{HCOOH} / \mathrm{HCN}$ ratios are above.

For a quantitative investigation, the temporal evolution of the volume mixing ratio $M_{i}$ of species $i$ was assumed as

$\mathrm{d} M_{i} / \mathrm{d} t=-M_{i} / \tau_{i}-M_{i} / \tau$,

where $\tau_{i}$ is the chemical lifetime and $\tau$ the time constant for mixing or dilution (Ehhalt et al., 1998). When this simple model is applied, the effect of mixing is cancelled by using ratios, leading to

$\left(M_{i} / M_{j}\right)(t)=\left(M_{i}^{0} / M_{j}^{0}\right) \times \exp \left(-t /\left(\tau_{i}+\tau_{j}\right)\right)$,

with $t=$ time and $M_{i}^{0} / M_{j}^{0}=$ enhancement ratio for $t=0$. Exponential curve fits were performed to measured and modelled time series of enhancement ratios, with fit parameters $a=M_{i}^{0} / M_{j}^{0}$ and $b=\tau_{i}+\tau_{j}$. Assuming a known lifetime of 160 days for $\mathrm{HCN}$ (Li et al., 2003), the chemical lifetimes of $\mathrm{C}_{2} \mathrm{H}_{2}$ and $\mathrm{HCOOH}$ can be calculated according to

$1 / \tau_{i}=1 / \tau_{\mathrm{hcn}}+1 /\left(\tau_{i}+\tau_{\mathrm{hcn}}\right)$.

Figure 16 shows measured and modelled time series of $\mathrm{C}_{2} \mathrm{H}_{2} / \mathrm{HCN}$ and $\mathrm{HCOOH} / \mathrm{HCN}$ enhancement ratios and the respective exponential fits. The resulting e-folding lifetimes for measured $\mathrm{C}_{2} \mathrm{H}_{2}$ are 17.3 and 16.0 days for 7-day and 3day temporal bins, respectively (Table 3 ). In good agreement, the fitted lifetime of modelled $\mathrm{C}_{2} \mathrm{H}_{2}$ is 18 days. The measured lifetime of $\mathrm{HCOOH}$ is 8.2 and 9.4 days for 7 - and 3-day binning, which is somewhat lower than the model lifetime of 12.2 days. Both measured and modelled $\mathrm{HCOOH}$ lifetimes are within the range of published estimates.

To assess the dependance of calculated lifetimes on the altitude range chosen for correlation, the same analysis was performed for measured and model data of the height range $15-18 \mathrm{~km}$. The lifetimes calculated from the model data were not much different, namely 17.4 and 12.6 days for $\mathrm{C}_{2} \mathrm{H}_{2}$ and $\mathrm{HCOOH}$, respectively. The lifetime of $\mathrm{HCOOH}$ calculated from MIPAS data for 7-day bins also changed only slightly to 8.0 days, whereas the lifetime of $\mathrm{C}_{2} \mathrm{H}_{2}$ increased to 20.1 days.

\section{Summary and conclusions}

The intense Australian bushfires of 7 February 2009 caused an injection of large amounts of various biomass burning products into the upper troposphere and lower stratosphere. Various combustion products of this fire event were observed by MIPAS on Envisat. In comparison with a dedicated 

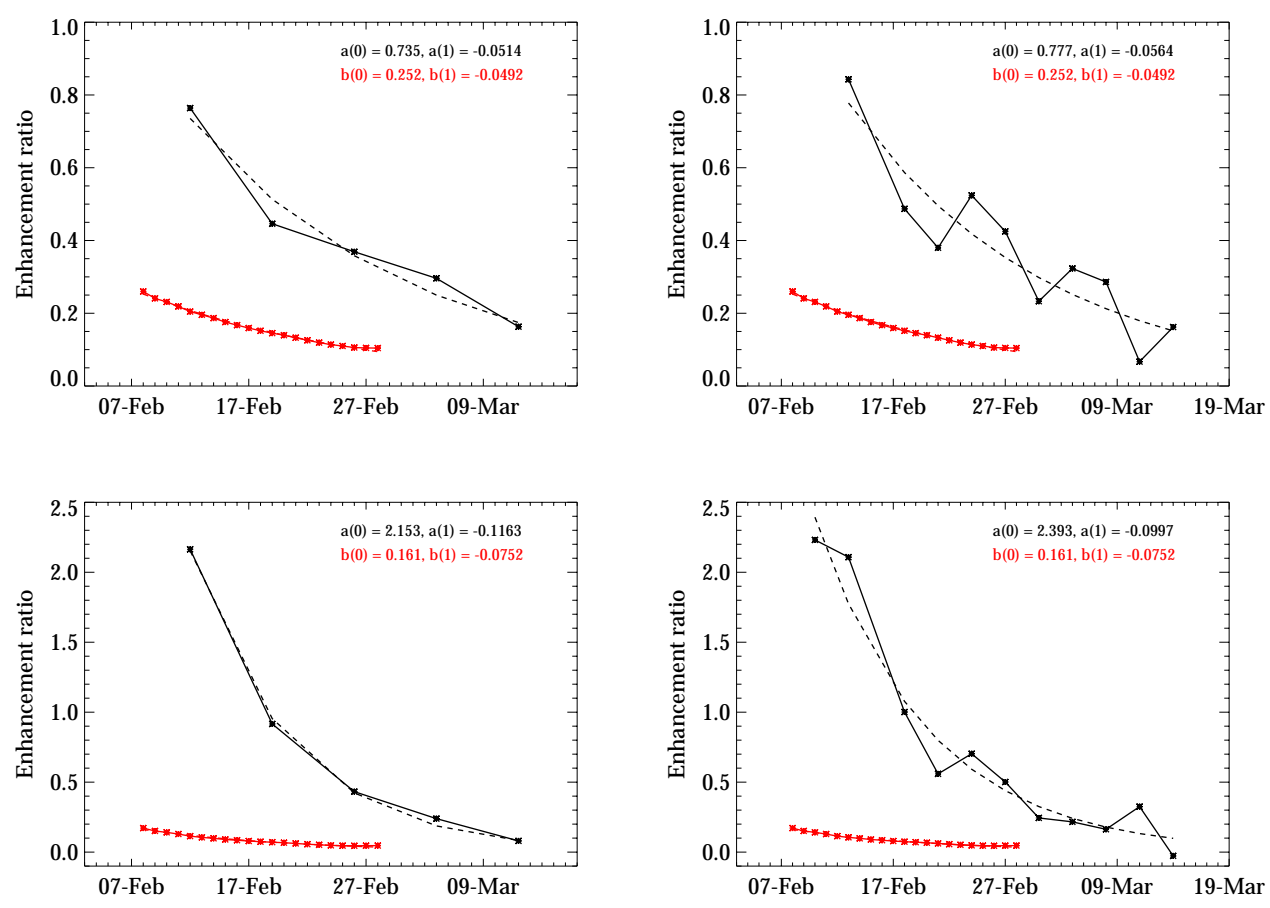

Fig. 16. Top: time series of measured (solid black curves with symbols) and modelled $\mathrm{C}_{2} \mathrm{H}_{2} / \mathrm{HCN}$ enhancement ratios (solid red curves with symbols). Measured time series are for the altitude region 17-21 km and 7-day (left) as well as 3-day bins (right), modelled time series for levels 4-11 ( 17-21 km) and 1-day bins. Dashed curves are two-parameter exponential fits (hardly visible for model data). Bottom: same as top panel, but for $\mathrm{HCOOH} / \mathrm{HCN}$ enhancement ratios.

Table 3. Calculated e-folding lifetimes (in days) of measured (MIPAS) and modelled (GEM-AQ) enhanced $\mathrm{C}_{2} \mathrm{H}_{2}$ and $\mathrm{HCOOH}$ in the plume released by the Australian bushfires of February 2009. Model levels 4-11 approximately correspond to the height region $17-21 \mathrm{~km}$. "Temp. bin" is the length of subsequent periods used for correlation, "d" = days.

\begin{tabular}{lrrr}
\hline MIPAS & $\begin{array}{r}\text { Height } \\
\text { region [km] }\end{array}$ & $\begin{array}{r}\text { Temp. } \\
\text { bin [d] }\end{array}$ & $\begin{array}{r}\text { Lifetime } \\
{[\mathrm{d}]}\end{array}$ \\
\hline $\mathrm{C}_{2} \mathrm{H}_{2}$ & $17-21$ & 7 & 17.3 \\
$\mathrm{C}_{2} \mathrm{H}_{2}$ & $17-21$ & 3 & 16.0 \\
$\mathrm{HCOOH}$ & $17-21$ & 7 & 8.2 \\
$\mathrm{HCOOH}$ & $17-21$ & 3 & 9.4 \\
\hline GEM-AQ & Model & Temp. & Lifetime \\
& levels & bin [d] & \\
\hline $\mathrm{C}_{2} \mathrm{H}_{2}$ & $4-11$ & 1 & 18.0 \\
$\mathrm{HCOOH}$ & $4-11$ & 1 & 12.2 \\
\hline
\end{tabular}

GEM-AQ model run for the largest of these fires, the horizontal expansion of the plume could unambiguously be tracked by MIPAS $\mathrm{C}_{2} \mathrm{H}_{2}, \mathrm{HCN}$ and $\mathrm{HCOOH}$ single-scan data over more than two weeks.

Enhanced values of $\mathrm{C}_{2} \mathrm{H}_{2}, \mathrm{HCN}$ and $\mathrm{HCOOH}$ were nearly always measured at the same geolocations. Further there is a remarkable agreement in measured and modelled plume expansion. These findings demonstrate the reliability of MIPAS single-scan data for tracking of biomass burning plumes. Both MIPAS and the GEM-AQ show a fast eastward transport of the pollutants to New Zealand within one day and its persistence northeastward of New Zealand during the following days. Starting on 14 February, the lower part of the plume was transported further eastward to southern South America, followed by a second relic some days later. After 20 February the upper (stratospheric) part of the plume was tracked moving westward towards Africa, which was reached at the beginning of March. The model plume was directly injected into altitudes of $14-18 \mathrm{~km}$ as early as 7 February. MIPAS did not sample the central part of the model plume during the first days and thus can neither confirm nor refute these early high altitudes of the model plume. Measured plume altitudes increased up to $14.5 \mathrm{~km}$ on 10 February and up to $15-17 \mathrm{~km}$ on 11 February, which indicates fast upward transport during these days. First evidence of injection of pollutants into the stratosphere was found in MIPAS data of 11 February, followed by larger amounts on 17 February. During the first 7 days after the outbreak of the fire, even the smoothed model volume mixing ratios of the biomass burning products at 15$18 \mathrm{~km}$ were much higher than those of MIPAS. One reason for the difference obviously is non-coverage of the central part of the plume by MIPAS especially during the first 4 days. 
Another reason is direct injection of the major part of plume into the altitude region $14-18 \mathrm{~km}$. According to MIPAS data, a significant part of the pollutants was released at lower altitudes. A further possible reason is the assumption of too high fire emissions.

To study plume aging, measured and modelled $\mathrm{C}_{2} \mathrm{H}_{2}$ and $\mathrm{HCOOH}$ were correlated with $\mathrm{HCN}$ for consecutive time periods. For the first time periods, $\mathrm{C}_{2} \mathrm{H}_{2} / \mathrm{HCN}$ and $\mathrm{HCOOH} / \mathrm{HCN}$ enhancement ratios of 0.76 and 2.16 were calculated, which is considerably higher than the emission ratios of 0.33 and 0.25 derived from the model data. Comparison with literature values shows that the measured emission ratios are within $\left(\mathrm{C}_{2} \mathrm{H}_{2}\right)$ or above $(\mathrm{HCOOH})$ the published ranges. Assuming a known lifetime of 160 days for $\mathrm{HCN}$, lifetimes of 16-20 and of 18 days were calculated for measured and modelled $\mathrm{C}_{2} \mathrm{H}_{2}$ from the temporal development of the enhancement ratios. The lifetimes calculated for measured and modelled $\mathrm{HCOOH}$ are 8-9 days and 12 days, respectively.

\section{Supplementary material related to this article is available online at: http://www.atmos-chem-phys.net/13/ 1637/2013/acp-13-1637-2013-supplement.zip.}

Acknowledgements. The authors like to thank the European Space Agency for giving access to MIPAS level-1 data. Meteorological analysis data have been provided by ECMWF. GEM-AQ model runs were performed in the frame of the ESA study "PREMIER Consolidation of Requirements and Synergistic Retrieval Algorithms" (contract number 22848/09/NL/CT). We acknowledge support by Deutsche Forschungsgemeinschaft and the Open Access Publishing Fund of Karlsruhe Institute of Technology. J. C. McConnell, K. Semeniuk, A. Lupu and J. W. Kaminski acknowledge support from the IMPACTS contract (number 4000101294/10/NL/CBi) and also Canadian Space Agency grants.

The service charges for this open access publication

have been covered by a Research Centre of the

Helmholtz Association.

Edited by: A. Geer

\section{References}

Akagi, S. K., Yokelson, R. J., Wiedinmyer, C., Alvarado, M. J., Reid, J. S., Karl, T., Crounse, J. D., and Wennberg, P. O.: Emission factors for open and domestic biomass burning for use in atmospheric models, Atmos. Chem. Phys., 11, 4039-4072, doi:10.5194/acp-11-4039-2011, 2011.

Andreae, M. O. and Merlet, P.: Emission of trace gases and aerosols from biomass burning, Global Biogeochem. Cy., 15, 955-966, doi:10.1029/2000GB001382, 2001.
Cicerone, R. J. and Zellner, R.: The Atmospheric Chemistry of Hydrogen Cyanide (HCN), J. Geophys. Res., 88, 10689-10696, 1983.

Clarisse, L., R'Honi, Y., Coheur, P.-F., Hurtmans, D., and Clerbaux, C.: Thermal infrared nadir observations of 24 atmospheric gases, Geophys. Res. Lett., 38, L10802, doi:10.1029/2011GL047271, 2011.

Côté, J., Gravel, S., Méthot, A., Patoine, A., Roch, M., and Staniforth, A.: The operational CMC MRB Global Environmental Multiscale (GEM) Model. Part I: Design considerations and formulation, Mon. Weather Rev., 126, 1373-1395, 1998a.

Côté, J., Desmarais, J.-G., Gravel, S., Méthot, A., Patoine, A., Roch, M., and Staniforth, A.: The operational CMCMRB Global Environmental Multiscale (GEM) Model. Part II: Results, Mon. Weather Rev., 126, 1397-1418, 1998b.

de Laat, A. T. J., Stein Zweers, D. C., Boers R., and Tuinder O. N. E.: A solar escalator: Observational evidence of the self-lifting of smoke and aerosols by absorption of solar radiation in the February 2009 Australian Black Saturday plume, J. Geophys. Res., 117, D04204, doi:10.1029/2011JD017016, 2012.

Donnell, E. A., Fish, D. J., Dicks, E. M., and Thorpe, A. J.: Mechanisms for pollutant transport between the boundary layer and the free troposphere, J. Geophys. Res., 106, 7847-7856, doi:10.1029/2000JD900730, 2001.

Ehhalt, D. H., Rohrer F., Wahner A., Prather, M. J. and Blake D. R., On the use of hydrocorbons for the determination of tropospheric OH concentrations, J. Geophys. Res., 103, 18981-18997, 1998.

European Space Agency: Envisat, MIPAS An instrument for atmospheric chemistry and climate research, ESA Publications Division, ESTEC, P.O. Box 299, 2200 AG Noordwijk, The Netherlands, SP-1229, 2000.

Fischer, H., Birk, M., Blom, C., Carli, B., Carlotti, M., von Clarmann, T., Delbouille, L., Dudhia, A., Ehhalt, D., Endemann, M., Flaud, J. M., Gessner, R., Kleinert, A., Koopman, R., Langen, J., López-Puertas, M., Mosner, P., Nett, H., Oelhaf, H., Perron, G., Remedios, J., Ridolfi, M., Stiller, G., and Zander, R.: MIPAS: an instrument for atmospheric and climate research, Atmos. Chem. Phys., 8, 2151-2188, doi:10.5194/acp-8-2151-2008, 2008.

Funke, B., López-Puertas, M., García-Comas, M., Stiller, G. P., von Clarmann, T., Höpfner, M., Glatthor, N., Grabowski, U., Kellmann, S., and Linden, A.: Carbon monoxide distributions from the upper troposphere to the mesosphere inferred from $4.7 \mu \mathrm{m}$ non-local thermal equilibrium emissions measured by MIPAS on Envisat, Atmos. Chem. Phys., 9, 2387-2411, doi:10.5194/acp-92387-2009, 2009.

Glatthor, N., von Clarmann, T., Stiller, G. P., Funke, B., Koukouli, M. E., Fischer, H., Grabowski, U., Höpfner, M., Kellmann, S., and Linden, A.: Large-scale upper tropospheric pollution observed by MIPAS HCN and $\mathrm{C}_{2} \mathrm{H}_{6}$ global distributions, Atmos. Chem. Phys., 9, 9619-9634, doi:10.5194/acp-9-9619-2009, 2009.

Goode, J. G., Yokelson, R. J., Ward, D. E., Susott, R. A., Babbitt, R. E., Davies, M. A., and Hao, W. M.: Measurements of excess $\mathrm{O}_{3}, \mathrm{CO}_{2}, \mathrm{CO}, \mathrm{CH}_{4}, \mathrm{C}_{2} \mathrm{H}_{4}, \mathrm{C}_{2} \mathrm{H}_{2}, \mathrm{HCN}, \mathrm{NO}, \mathrm{NH}_{3}$, $\mathrm{HCOOH}, \mathrm{CH}_{3} \mathrm{COOH}, \mathrm{HCHO}$, and $\mathrm{CH}_{3} \mathrm{OH}$ in 1997 Alaskan biomass burning plumes by airborne Fourier transform infrared spectroscopy (AFTIR), J. Geophys. Res., 105, 22147-22166, 2000. 
Grutter, M., Glatthor, N., Stiller, G. P., Fischer, H., Grabowski, U., Höpfner, M., Kellmann, S., Linden, A., and von Clarmann, T.: Global distribution and variability of formic acid as observed by MIPAS-ENVISAT, J. Geophys. Res., 115, D10303, doi:10.1029/2009JD012980, 2010.

Höpfner, M., von Clarmann, T., Fischer, H., Glatthor, N., Grabowski, U., Kellmann, S., Kiefer, M., Linden, A., Mengistu Tsidu, G., Milz, M., Steck, T., Stiller, G. P., Wang, D.-Y., and Funke, B.: First spaceborne observations of Antarctic stratospheric $\mathrm{ClONO}_{2}$ recovery: Austral spring 2002, J. Geophys. Res., 109, D11308, doi:10.1029/2004JD004609, 2004.

Kahn, R. A., Li, W.-H., Moroney, C., Diner, D. J., Martonchik, J. V., and Fishbein, E.: Aerosol source plume physical characteristics from space-based multiangle imaging, J. Geophys. Res., 112, D11205, doi:10.1029/2006JD007647, 2007.

Kaminski, J. W., Neary, L., Struzewska, J., McConnell, J. C., Lupu, A., Jarosz, J., Toyota, K., Gong, S. L., Côté, J., Liu, X., Chance, K., and Richter, A.: GEM-AQ, an on-line global multiscale chemical weather modelling system: model description and evaluation of gas phase chemistry processes, Atmos. Chem. Phys., 8, 3255-3281, doi:10.5194/acp-8-3255-2008, 2008.

Keene, W. C. and Galloway, J. N.: The biogeochemical cycling of formic and acetic acids through the troposphere: An overview of current understanding, Tellus B, 40, 322-334, 1988.

Leng, L., Zhang, T., Kleinman, L., and Zhu, W.: Ordinary Least Square Regression, Orthogonal Regression, Geometric Mean Regression and their application in Aerosol Science, J. of Phys., Conference Series 78, doi:10.1088/17426596/78/1/012084, 2007.

Li, Q., Jacob, D. J., Yantosca, R. M., Heald, C. L., Singh, H. B., Koike, M., Zhao. Y., Sachse, G. W., and Streets, D. G.: A global three-dimensional model analysis of the atmospheric budgets of $\mathrm{HCN}$ and $\mathrm{CH}_{3} \mathrm{CN}$ : Constraints from aircraft and ground measurements, J. Geophys. Res., 108, 8827, doi:10.1029/2002JD003075, 2003.

Lupu, A., Kaminski, J. W., Neary, L., McConnell, J. C., Toyota, K., Rinsland, C. P., Bernath, P. F., Walker, K. A., Boone, C. D., Nagahama, Y., and Suzuki, K.: Hydrogen cyanide in the upper troposphere: GEM-AQ simulation and comparison with ACE-FTS observations, Atmos. Chem. Phys., 9, 4301-4313, doi:10.5194/acp9-4301-2009, 2009.

Mu, M., Randerson, J. T., van der Werf, G. R., Giglio, L., Kasibhatla, P., Morton, D., Collatz, G. J., DeFries, R. S., Hyer, E. J., Prins, E. M., Griffith, D. W. T., Wunch, D., Toon, G. C., Sherlock, V., and Wennberg, P. O.: Daily and 3-hourly variability in global fire emissions and consequences for atmospheric model predictions of carbon monoxide, J. Geophys. Res., 116, D24303, doi:10.1029/2011JD016245, 2011.

Nett, H., Perron, G., Sanchez, M., Burgess, A., and Mossner, P.: MIPAS inflight calibration and processor validation, in ENVISAT Calibration Review - Proc. of the European Workshop, 9-13 September 2002, ESTEC, Noordwijk, The Netherlands, CDROM, vol. SP-520, edited by: Sawaya-Lacoste, H., ESA Publications Division, ESTEC, Postbus 299, 2200 AG Noordwijk, The Netherlands, 2002.

Park, M., Randel, W. J., Emmons, L. K., Bernath, P. F., Walker, K. A., and Boone, C. D.: Chemical isolation in the Asian monsoon anticyclone observed in Atmospheric Chemistry Experiment (ACE-FTS) data, Atmos. Chem. Phys., 8, 757-764, doi:10.5194/acp-8-757-2008, 2008.

Pumphrey, H. C., Santee, M. L., Livesey, N. J., Schwartz, M. J., and Read, W. G.: Microwave Limb Sounder observations of biomassburning products from the Australian bush fires of February 2009, Atmos. Chem. Phys., 11, 6285-6296, doi:10.5194/acp-116285-2011, 2011.

Remedios, J. J., Leigh, R. J., Waterfall, A. M., Moore, D. P., Sembhi, H., Parkes, I., Greenhough, J., Chipperfield, M. P., and Hauglustaine, D.: MIPAS reference atmospheres and comparisons to V4.61/V4.62 MIPAS level 2 geophysical data sets, Atmos. Chem. Phys. Discuss., 7, 9973-10017, doi:10.5194/acpd-79973-2007, 2007.

Rinsland, C. P., Meier, A., Griffith D. W. T., and Chiou, L. S. Ground-based measurements of tropospheric $\mathrm{CO}, \mathrm{C}_{2} \mathrm{H}_{6}$, and $\mathrm{HCN}$ from Australia at $34^{\circ} \mathrm{S}$ latitude during 1997-1998, J. Geophys. Res., 106, 20913-20924, 2001.

Rinsland, C. P., Dufour, G., Boone, C. D., and Bernath, P. F.: Atmospheric Chemistry Experiment (ACE) measurements of elevated Southern Hemisphere upper tropospheric $\mathrm{CO}, \mathrm{C}_{2} \mathrm{H}_{6}$, $\mathrm{HCN}$, and $\mathrm{C}_{2} \mathrm{H}_{2}$ mixing ratios from biomass burning emissions and long range transport, Geophys. Res. Lett., 32, L20803, doi:10.1029/2005GL024214, 2005.

Rudolph, J., Ehhalt, D. H., and Khedim, A.: Vertical Profiles of Acetylene in the Troposphere and Stratosphere, J. Atmos. Chem., 2, 117-124, 1984.

Siddaway, J. M. and Petelina, S. V.: Transport and evolution of the 2009 Australian Black Saturday bushfire smoke in the lower stratosphere observed by OSIRIS on Odin, J. Geophys. Res., 116, D06203, doi:10.1029/2010JD015162, 2011.

Singh, H. B., Herlth, D., Kolyer, R., Chatfield, R., Viezee, W., Salas, L. J., Chen, Y., Bradshaw, J. D., Sandholm, S. T., Talbot, R., Gregory, G. L., Anderson, B., Sachse, G. W., Browell, E., Bachmeier, A. S., Blake, D. R., Heikes, B., Jacob, D., and Fuelberg, H. E.: Impact of biomass burning emissions on the composition of the South Atlantic troposphere: Reactive nitrogen and ozone, J. Geophys. Res., 101, 24203-24219, 1996.

Singh, H. B., Viezee, W., Chen, Y., Bradshaw, J., Sandholm, S., Blake, D., Blake, N., Heikes, B., Snow, J., Talbot, R., Browell, E., Gregory, G., Sachse, G., and Vay, S.: Biomass burning influences on the composition of the remote South Pacific troposphere: analysis based on observations from PEM-Tropics-A, Atmos. Environ., 34, 635-644, 2000.

Singh, H. B., Salas, L., Herlth, D., Kolyer, R., Czech, E., Viezee, W., Li, Q., Jacob, D. J., Blake, D., Sachse, G., Harward, C. N., Fuelberg, H., Kiley, C. M., Zhao, Y., and Kondo, Y. : In situ measurements of $\mathrm{HCN}$ and $\mathrm{CH}_{3} \mathrm{CN}$ over the Pacific Ocean: Sources, sinks and budgets, J. Geophys. Res., 108, 8795, doi:10.1029/2002JD003006, 2003.

Stavrakou, T., Müller, J.-F., Peeters, J., Razavi, A., Clarisse, L., Clerbaux, C., Coheur, P.-F., Hurtmans, D., De Mazière, M., Vigouroux, C., Deutscher, N. M., Griffith, D. W. T. Jones, N., and Paton-Walsh, C.: Satellite evidence for a large source of formic acid from boreal and tropical forests, Nature Geosci., 5, 26-30, doi:10.1038/NGEO1354, 2012.

Steck, T.: Methods for determining regularization for atmospheric retrieval problems, Appl. Opt., 41, 1788-1797, 2002.

Stiller, G. P. (Ed.): The Karlsruhe Optimized and Precise Radiative transfer Algorithm (KOPRA), Institut für Meteorologie und Klimaforschung, Forschungszentrum Karlsruhe GmbH, 2000. 
Teague, B., McLeod, D., and Pascoe, S.: 2009 Victorian Bushfires Royal Commission - Final Report, Tech. rep., available at: http://www.royalcommission.vic.gov.au/Commission-Reports/ Final-Report, 2010.

Tolhurst, K.: Report on the Physical Nature of the Victorian Fires occurring on 7th February 2009, Commissioned report to the Victorian Bushfires Royal Commission, 18 pp., available at: http://www.royalcommission.vic.gov.au/getdoc/ 5905c7bb-48f1-4d1d-a819bb2477c084c1/EXP.003.001.0017. pdf, 2009.

Tolhurst, K. G., Shields, B. J., and Chong, D. M.: PHOENIX: development and application of a bushfire risk management tool, Australian Journal of Emergency Management, 23, 47-54, 2008.

Trentmann, J., Luderer, G., Winterrath, T., Fromm, M. D., Servranckx, R., Textor, C., Herzog, M., Graf, H.-F., and Andreae, M. O.: Modeling of biomass smoke injection into the lower stratosphere by a large forest fire (Part I): reference simulation, Atmos. Chem. Phys., 6, 5247-5260, doi:10.5194/acp-65247-2006, 2006.

von Clarmann, T., Fischer, H., Funke, B., Glatthor, N., Grabowski, U., Höpfner, M., Kellmann, S., Kiefer, M., Linden, A., Mengistu Tsidu, G., Milz, M., Steck, T., Stiller, G.P., Wang, D.-Y., GilLópez, S., and López-Puertas, M.: Retrieval of temperature and tangent altitude pointing from limb emission spectra recorded from space by the Michelson Interferometer for Passive Atmospheric Sounding (MIPAS), J. Geophys. Res., 108, 4736, doi:10.1029/2003JD003602, 2003.

von Clarmann, T., Glatthor, N., Koukouli, M. E., Stiller, G. P., Funke, B., Grabowski, U., Höpfner, M., Kellmann, S., Linden, A., Milz, M., Steck, T., and Fischer, H.: MIPAS measurements of upper tropospheric $\mathrm{C}_{2} \mathrm{H}_{6}$ and $\mathrm{O}_{3}$ during the southern hemispheric biomass burning season in 2003, Atmos. Chem. Phys., 7, 5861-5872, doi:10.5194/acp-7-5861-2007, 2007. von Clarmann, T., Höpfner, M., Kellmann, S., Linden, A., Chauhan, S., Funke, B., Grabowski, U., Glatthor, N., Kiefer, M., Schieferdecker, T., Stiller, G. P., and Versick, S.: Retrieval of temperature, $\mathrm{H}_{2} \mathrm{O}, \mathrm{O}_{3}, \mathrm{HNO}_{3}, \mathrm{CH}_{4}, \mathrm{~N}_{2} \mathrm{O}, \mathrm{ClONO}_{2}$ and $\mathrm{ClO}$ from MIPAS reduced resolution nominal mode limb emission measurements, Atmos. Meas. Tech., 2, 159-175, doi:10.5194/amt-2-159-2009, 2009.

van der Werf, G. R., Randerson, J. T., Giglio, L., Collatz, G. J., Mu, M., Kasibhatla, P. S., Morton, D. C., DeFries, R. S., Jin, Y., and van Leeuwen, T. T.: Global fire emissions and the contribution of deforestation, savanna, forest, agricultural, and peat fires (19972009), Atmos. Chem. Phys., 10, 11707-11735, doi:10.5194/acp10-11707-2010, 2010.

Wiegele, A., Glatthor, N., Höpfner, M., Grabowski, U., Kellmann, S., Linden, A., Stiller, G., and von Clarmann, T.: Global distributions of $\mathrm{C}_{2} \mathrm{H}_{6}, \mathrm{C}_{2} \mathrm{H}_{2}, \mathrm{HCN}$, and PAN retrieved from MIPAS reduced spectral resolution measurements, Atmos. Meas. Tech., 5, 723-734, doi:10.5194/amt-5-723-2012, 2012.

Xiao, Y., Jacob, D. J., and Turquety, S.: Atmospheric acetylene and its relationship with $\mathrm{CO}$ as an indicator of air mass age, J. Geophys. Res., 112, D12305, doi:10.1029/2006JD008268, 2007.

Yokelson, R. J., Bertschi, I. T., Christian, T. J., Hobbs, P. V., Ward, D. E., and Hao, W. M.: Trace gas measurements in nascent, aged, and cloud-processed smoke from African savanna fires by airborne Fourier transform infrared spectroscopy (AFTIR), J. Geophys. Res., 108, 8478, doi:10.1029/2002JD002322, 2003.

Yokelson, R. J., Christian, T. J., Karl, T. G., and Guenther, A.: The tropical forest and fire emissions experiment: laboratory fire measurements and synthesis of campaign data, Atmos. Chem. Phys., 8, 3509-3527, doi:10.5194/acp-8-3509-2008, 2008. 